Оригинални научни рад

339.727.22:621.039]:341.6

Maja Stanivuković, Ph.D., Full Professor

Faculty of Law Novi Sad

\title{
STATE-INVESTOR DISPUTES CONNECTED TO \\ FOREIGN INVESTMENTS IN THE NUCLEAR ENERGY SECTOR: A REVIEW OF THE TWO CASES ARISING UNDER THE ENERGY CHARTER TREATY ${ }^{1}$
}

\begin{abstract}
The idea of foreign investments in nuclear energy sector is relatively new. Foreign investors were for a long time denied an opportunity to invest in the sector which was considered to be too sensitive for reasons of safety and security. Together with the change of an attitude towards foreign private investment in this area a possibility of disputes between foreign investors and the host State also emerged. The Energy Charter Treaty represents the only currently existing comprehensive legal instrument of multilateral character which specifically provides for protection of foreign investments in the energy sector against non-commercial risks and establishes a mechanism for resolution of investment disputes. The article contains a review of the cases of HEP $v$. Slovenia and AMTO v. Ukraine, the only two arbitrations that have arisen so far under the ECT from disputes concerning foreign investments in the nuclear sector. Their analysis shows that the involvement of State in this sector is indispensable but it should be exercised with respect for rights of investors protected by international law. Regulatory measures introduced by the State to protect certain important interest, such as public health, safety, security or the environment, may be perceived by the investor as having equivalent effect to expropriation. Regulatory uncertainty is considered to be one of the main deterrents to investment in new nuclear plants. ${ }^{2}$

1 Рад је посвећен пројекту Биомедицина, заштита животне средине и право бр. 179079 који финансира Министарство просвете и науке Републике Србије.

${ }^{2}$ Financing of New Nuclear Power Plants, IAEA Nuclear Energy Series, 2008, p. 6.
\end{abstract}


Key words: foreign investments, nuclear energy, Energy Charter Treaty, HEP v. Slovenia, AMTO v. Ukraine

\section{Foreign Direct Investment in Nuclear Sector}

In many countries the main investor in the nuclear power plants was the State. For a long time private investor was perceived as too weak or too risky to engage in the venture of such a magnitude. More recently the attitude has changed. Privatization of nuclear energy industry is conceivable and in many countries already a reality. Private investment is the main financing source for new build projects.

Nuclear energy production is a heavily regulated sector. There are many safety and security concerns that have to be provided for. The State as the regulator has always been indispensible. International obligations that the State must observe, in particular with regard to nuclear safety, nuclear security and nonproliferation require adequate legal powers and instruments. The observance of these obligations may occasionally require interference with rights of the investor, or foreign investor, as the case may be. These obligations may increase over time, with raising of standards and public expectations.

The idea of foreign investment in the nuclear energy sector is relatively new. Nuclear is considered to be a sensitive sector from which foreign investors have been excluded in many countries, such as India, Mexico, Canada, and Japan. However, there are indications of change in that respect, too. The current trend is to liberalize foreign direct investments even in the sensitive fields. Traditional government or domestic majority ownership requirements are being relaxed..$^{3}$ Notably, OECD has issued guidelines to countries on how to treat foreign investments in sensitive sectors. ${ }^{4}$

Some countries are following suit as far as production of nuclear energy is concerned. Thus, Russian Deputy Prime Minister, Sergey Ivanov stated in 2008: "In addition to large-scale investment of state funds, we have grounds to count on substantial private investment. The Russian nuclear sector is now open to cooperation. Furthermore, not only with domestic businesses, but also with foreign investors." At the same time, Russia's Nuclear Power Agency Rosatom director stated that Russia is ready to invest in NPP projects abroad. ${ }^{5}$ In an arti-

${ }^{3}$ T. W. Wälde, International Energy Investment, 17 Energy Law Journal, 191-215 (1996), p. 193.

4 Guidelines for Recipient Investment Policies Relating to National Security, Recommendation adopted by the OECD Council on 25 May 2009.Accessible at: http://www.oecd.org/dataoecd/11/35/43384486.pdf

${ }^{5}$ Russia Says Nuclear Sector Open to Foreign Investment, Nuclear Power Daily, July 2, 2008, Accessible at: http://www.nuclearpowerdaily.com/ 
cle published in the Nuclear Energy Insider on 14 January 2010, the British journalist Jack Craze is urging the UK legislator to go forward in the same direction: „Keen to remain at the forefront of nuclear power, the French Government has just pledged EUR 1bn to fund next-generation nuclear development and it is throwing open the door to foreign investment in the French power market. The UK has to move quickly if it is to create an attractive environment for investment in nuclear and other low carbon industries." ${ }^{\text {"6 }}$ These statements seem to herald the age when we are bound to see the rise in foreign direct investment in nuclear industry.

There are huge commercial and non-commercial risks involved with every nuclear power plant investment that have to be taken into account and provided for in advance. Commercial risks include possibility that the investor will not be able to ensure profitable rate of return or repayment of credits due to market conditions, cost overruns, and project delays. ${ }^{7}$ Non-commercial risks flow from a regulatory or fiscal climate that is unstable or draconic, monetary restrictions that prevent repatriation of profit and capital, fluctuation of exchange rates, political unrest or war. In addition to regular commercial risks the nuclear investor may have to provide for the costs of storage and processing of spent nuclear fuel and decommissioning, and insure against any damages that may arise from a nuclear accident, because, pursuant to international treaties, nuclear operator is the sole liable person, and must obtain proper insurance. ${ }^{8}$ Preparatory costs for investing in a nuclear power plant may spiral - these are multibillion dollar projects -- and the investor will have to bear them if the investment fails. One can take as example the Long Island Lighting Company's decision to build and operate the Shoreham Nuclear Power Plant in 1966. The plant's cost was estimated to be 75 million dollars when the project was announced, but it rose over the following 23 years to over 5 billion. Finally, the company negotiated an agreement with the New York State and abandoned Shoreham before it ever begun operation. ${ }^{9}$ There may also be environmental problems either within

${ }^{6}$ J. Craze, If we build, will they come? 14 January 2010, Nuclear Energy Insider, Accessible at: http://analysis.nuclearenergyinsider.com/

${ }^{7}$ For an overview of these risks and ways to mitigate them, see: Financing of New Nuclear Power Plants, IAEA Nuclear Energy Series, 2008, p. 6. Accessible at: http://wwwpub.iaea.org/MTCD/publications/PDF/Pub1345_web.pdf.

${ }^{8}$ Pusuant to Paris Convention on Third Party Liability in the Field of Nuclear Energy of 29 July 1960, as amended by the Additional Protocol of 28 January 1964, and by the Protocol of 16 November 1982, Arts. 3 and 10, and Vienna Convention on Civil Liability for Nuclear Damage dated May 21, 1963, IAEA INFCIRC/500, Arts. II and VII; See also the Joint Protocol Relating to the Application of the Vienna Convention and the Paris Convention of 21 September 1988 INFCIRC/402.

9 J.Ross, B.M.Staw, Organizational Escalation and Exit: Lessons From the Shoreham Nuclear Power Plant Academy of Management Journal 1993, vol. 36, no. 4 p. 701. 
the host country or with neighboring countries - such as in the Mox Plant Case. ${ }^{10}$ If the operator is a foreign investor, or a foreign controlled company, these risks become more complex, involve multiplicity of actors, and may create a potential for an international dispute.

International legal framework for foreign investment in nuclear energy sector is not fully developed. It is still emerging. ${ }^{11}$ Important part of it is the mechanism for resolution of any disputes that may arise in the course of the foreign investment. The Energy Charter Treaty represents a comprehensive legal instrument devoted to energy issues ${ }^{12}$ and includes a set of rules on investment and settlement of investment disputes. It is therefore worth looking into in search of answers for better regulation of and avoidance of any disputes arising from foreign investment in the nuclear energy sector.

\section{State as a Regulator}

Nuclear technology involves special risks. The permission and the continuous control principles as fundamental principles of nuclear law, ${ }^{13}$ require constant involvement of the State in regulation of activities related to nuclear energy. Pursuant to Art. 7 of the Convention on Nuclear Safety, ${ }^{14}$ each Contracting Party shall establish and maintain a legislative and regulatory framework to govern the safety of nuclear installations. The legislative framework shall provide for a system of licensing with regard to nuclear installations and the prohibition of the operation of a nuclear installation without a license, a system of regulatory inspection, and the enforcement of applicable regulations and of the terms of licenses, including suspension, modification and revocation. Pursuant to Art. 8, each Contracting Party shall establish a regulatory body entrusted with the implementation of the legislative and regulatory framework, and provided with adequate authority. Art. 14 requires the Contracting Parties to conduct comprehensive and systematic safety assessments before the construction and commissioning of a nuclear installation and throughout its life. Operating licenses for operation of nuclear power reactors are granted for a limited period of time, and the extensions may be conditioned upon making of necessary modifications. ${ }^{15}$

${ }^{10}$ Case C-459/03 Commission of the European Communities v. Ireland.

${ }^{11}$ A.A. Fatouros, An International Legal Framework for Energy, Recueil des cours, 2007, $355-443$, p.387.

${ }^{12}$ Ibidem, p. 409.

${ }^{13}$ C. Stoiber, A. Baer, N. Pelzer, W. Tonhauser, Handbook on Nuclear Law, IAEA, 2003, p. 5 .

${ }^{14}$ Convention on Nuclear Safety of 17 June 1994, IAEA INFCIRC/449.

${ }^{15}$ C. Stoiber, A. Baer, N. Pelzer, W. Tonhauser, op.cit., p. 67. 
The State also has critical international legal and political responsibilities for the activities of nuclear industry: evolving non-proliferation obligations, ${ }^{16}$ safeguards agreements, physical protection, ${ }^{17}$ and export-controls. ${ }^{18}$ Additionally, it has to lay down and enforce the environmental regulations and controls.

The fact that the State is deeply involved in the regulation of the nuclear production of energy, both at the time of investment and during the operation of the nuclear power plant gives rise to risk that the government may overstep the boundaries of legitimate intervention, and use its power to shift the balance of mutual costs and benefits between the investor and the host-State in its own favor, and to the detriment of the investor. The practice of investment arbitration has developed the concept of a "regulatory expropriation" - governmental regulation that substantially deprives the investor of the benefit of his investment - that may be of special importance in nuclear ventures. It will be particularly difficult in this sector to draw the line between legitimate intervention and expropriation.

During the recent two decades there has been an increase in disputes between investors and host states under bilateral treaties on promotion and protection of investments (BITs). The subject of a typical investment dispute is often whether a particular regulatory measure by the State amounted to a breach of its treaty obligations. This type of disputes may arise under the Energy Charter Treaty, as well. ${ }^{19}$

Regulatory measures introduced by the State to protect certain important interest, such as public health, safety, security or the environment, may be perceived by the investor as having equivalent effect to expropriation. It is highly controversial whether and under which circumstances such a regulatory measure may be subsumed under the definition of indirect expropriation. Indirect (concealed) expropriation is forbidden just as the outright expropriation, and the State may be liable for damages in case it is established that some of its regulatory measures caused such substantial consequences that they amounted to expropriation. ${ }^{20}$ Regulatory uncertainty is considered to be one of the main deterrents to investment in new nuclear plants. ${ }^{21}$

${ }^{16}$ Treaty on the Non-Proliferation of Nuclear Weapons, 1 July 1968, IAEA INFCIRC/140. For a discussion of Art. IV of the Convention see, R. Dolzer, International Nuclear Cooperation: Obligations, Conditions and Options, Indian Journal of International Law, Vol. 20, No. 3, JulySept. 1980, pp.366-394.

${ }^{17}$ Convention on the Physical Protection of Nuclear Material, 3 March 1980, IAEA INFCIRC/274/Rev. 1.

${ }_{18}$ See, M. Quentin, Constraints Imposed to International Nuclear Trade by Different Nuclear Export Control Regime, Compedium of International Legal Instruments in the Nuclear Energy Field, ISNL, 2009 Session, pp. 373-402.

19 R. Happ, Dispute Settlement Under the Energy Charter Treaty, German Yearbook of International Law, 2002, 331-362 p. 331.

${ }^{20}$ Ibidem, p. 342.

${ }^{21}$ Financing of New Nuclear Power Plants, IAEA Nuclear Energy Series, 2008, p. 6. 


\section{The Energy Charter Treaty}

Energy Charter Treaty (ECT) was signed in Lisabon, in December 1994, in the aftermath of the Cold War ${ }^{22}$ by 51 OECD, Eastern European and CIS countries and the European Communities. The text, adopted after three years of intensive negotiations, ${ }^{23}$ required thirty ratifications to enter into force. This happened rather fast, by January 1998, and the ECT came into force on 16 April 1998. Up to date, it has been ratified by 46 countries and the European Union. ${ }^{24}$ As it turns out, the major energy producer and signatory of the ECT, the Russian Federation, did not ratify it, and has indicated that it will not ratify it without substantial changes. ${ }^{25}$ Major world producers of energy such as Australia, Canada, China, India, Norway, and United States are also not among Contracting Parties, although some of them signed either the Treaty or the Charter. Nevertheless, the commentators agree that ECT is an important regional multilateral instrument. The fundamental aim of the Energy Charter Treaty is to strengthen the rule of law on energy issues. ${ }^{26}$ It is currently the only multilateral investment

${ }^{22}$ The plan for a European Energy Charter was first proposed on 25 June 1990 during the Dublin European Council by the Dutch Prime Minister, Ruud Lubbers. Its main goal was to provide for economic, technical and structural support for the post-communist states in Central and Eastern Europe via the benefits of an enlarged European energy network. See: "EEC Commission Presents Draft Pan-European Energy Charter", European Report of 16 February 1991, External Relations No 1653 at $\mathrm{p}$ 6. Cited according to: N. Horbach, Nuclear Protocol of the Energy Charter Treaty, Journal of Energy and Natural Resources Law, Vol. 13, 1995, 163-177, p. 164.

${ }^{23}$ R. Happ, op.cit., p. 332.

${ }^{24}$ Signatories States are: Albania, Armenia, Austria, Australia, Azerbaijan, Belarus, Belgium, Bosnia and Herzegovina, Bulgaria, Croatia, Czech Republic, Cyprus, Denmark, Estonia, European Communities, Finland, France, Georgia, Germany, Greece, Hungary, Iceland, Italy, Japan, Kazakhstan, Kyrgyzstan, Latvia, Liechtenstein, Lithuania, Luxembourg, Malta, Moldavia, Mongolia, Netherlands, Norway, Poland, Portugal, Romania, Russian Federation, Slovakia, Slovenia, Spain, Sweden, Switzerland, Tajikistan, The former Yugoslav Republic of Macedonia, Turkey, Turkmenistan, Ukraine, Uzbekistan, United Kingdom. Five Signatory States that have not yet ratified the ECT are Australia, Belarus, Iceland, Norway, and Russian Federation. For the status of ratifications, see Energy Charter Secretariat, Status of Ratification of The Energy Charter Treaty as of October 2009. http://www.encharter.org/ accessed on 1 December 2010.

${ }^{25}$ On 20 August 2009 the Russian Federation has officially informed the Depository that it did not intend to become a Contracting Party to the ECT. In accordance with Article 45(3(a)) of the Treaty, such notification results in Russia's termination of its provisional application of the ECT upon expiration of 60 calendar days from the date on which the notification is received by the Depository. See: Energy Charter Secretariat, Status of Ratification of The Energy Charter Treaty as of October 2009. For an explanation of reasons for non-ratification, see: R. Götz, Russian Gas and European Energy Sector, SWP Research Paper, German Institute for International and Security Affairs, Berlin, 2007, pp. 17-18. One of the reasons mentioned by the author is that the ECT has not covered trade in nuclear fuels.

26 Energy Charter Secretariat: The Energy Charter Treaty and Related Documents, Introduction, p. 14, accessible at: http://www.encharter.org/ 
treaty that deals specifically with the energy sector. ${ }^{27}$ The legal commentary on the ECT is already substantial, and will rise steadily as the importance of the Treaty is reaffirmed in practice. ${ }^{28}$

Originally, the principal aim of the negotiators was to provide an international legal and policy network for foreign investments in the oil and gas sector of the countries of the former Soviet Union and to increase the energy supplies to Western Europe. ${ }^{29}$ There were also concerns at that time about the safety of the nuclear power plants in Central and Eastern Europe and the Commonwealth of Independent States (CIS). ${ }^{30}$ A great need for investment was perceived in order to enable these countries to reconstruct and modernise their aging nuclear facilities. At the December 1990 Conference for Security and Co-operation in Europe Summit in Paris, Jacques Delors, President of the European Commission, advocated the European Energy Charter as a suitable means of modernisation and enhancement of the energy market, including nuclear energy, within the Central and Easter Europe and CIS. ${ }^{31}$

Special regard for the nuclear energy sector was reflected in the document that preceded the ECT - the European Energy Charter - that was adopted by signature of a Concluding Document at a European Energy Charter Conference held at The Hague on 16-17 December 1991. In the Declaration constituting the European Energy Charter the signatories emphasized their common interest in problems of energy supply and safety of industrial plants, particularly nuclear facilities, and environmental protection. ${ }^{32}$ They declared that they would take action to promote development of trade in energy consistent with major relevant multilateral agreements such as GATT, its related instruments, and nuclear nonproliferation obligations and undertakings. ${ }^{33}$ They further promised to take action to attain energy efficiency and environmental protection which would imply achieving and maintaining a high level of nuclear safety and ensuring effec-

${ }^{27}$ A. Turinov, "Investment" and "Investor" in Energy Charter Treaty Arbitration: Uncertain Jurisdiction, Arbitration International, 1-23 (2009), p. 3; E. Sussman, The Energy Charter Treaty's Investor Protection Provisions: Potential to Foster Solutions to Global Warming and Promote Sustainable Development, ILSA Journal of International \& Comparative Law, Vol. 14 No. 2, 391-404 (2008), 398.

${ }^{28}$ T.W. Wälde, The Energy Charter Treaty, An East-West Gateway for Investment and Trade, Kluwer Law International 1996; C. Ribeiro, ed. Investment Arbitration and the Energy Charter Treaty, Juris Publishing 2006.

${ }^{29}$ T.W. Wälde, International Energy Investment, p. 213.

${ }^{30}$ N. Hornbach, op.cit. p. 163.

${ }^{31}$ Ibidem, p. 164.

32 Energy Charter Secretariat: The Energy Charter Treaty and Related Documents, Concluding Document of The Hague Conference on the European Energy Charter, p. 212.

${ }^{33}$ Ibidem, p. 214. 
tive co-operation in this field. ${ }^{34}$ The signatories of the European Energy Charter also undertook the obligation to negotiate a Basic Agreement and Protocols that would pursue the objectives and principles of the Charter and promote EastWest industrial co-operation by providing legal safeguards in areas such as investment, transit and trade. Areas of co-operation to be covered by the future Basic Agreement included, inter alia, all aspects of the nuclear fuel cycle including improvements in safety in that sector. ${ }^{35}$ Parallel to negotiations on the Basic Agreement, which later became the ECT, the European Energy Charter Conference also began negotiations of several protocols, among which the Protocol on Nuclear Safety. ${ }^{36}$ The latter was never completed due to the fact that a competing instrument, covering mostly the same nuclear issues, was developed in the meantime within the auspices of the IAEA.$^{37}$ This was the Convention on Nuclear Safety of 17 June 1994. Most States that signed the Convention on Nuclear Safety would have been reluctant to sign the Nuclear Protocol, as well.

Eventually, the Contracting Parties have delimited a broader scope of application of the ECT than just investment in oil and gas sector. According to Art. 2, the purpose of the Treaty is to establish "a legal framework in order to promote long-term cooperation in the energy field, based on complementarities and mutual benefits, in accordance with the objectives and principles of the Charter." Consequently, it covers investments in all types of energy production, including nuclear energy. It also regulates trade in energy materials and products including their transit, with certain exceptions. Nuclear materials and fuels are covered through its definition of "Energy Materials and Products" under Article 1(4), by way of a cross reference to Annex EM that includes a list of nuclear materials and fuels. It should be noted, however, that while, the ECT regulates investment in the nuclear energy sector, trade in nuclear materials is for the time being excluded. ${ }^{38}$ For this reason, its investment provisions are of more relevance for the nuclear lawyer.

In summary, the ECT provides a comprehensive international framework for cross-border investment and trade in energy sector in the Euro-Asian region $^{39}$. It is one of the rare international instruments that provides rules and

${ }^{34}$ Ibidem, p. 215.

${ }^{35}$ Ibidem, p. 220.

${ }^{36}$ Energy Charter Secretariat: The Energy Charter Treaty and Related Documents, Final Act of the European Energy Charter Conference, p. 24.

${ }^{37}$ N. Hornbach, op.cit. p. 176.

${ }^{38}$ Energy Charter Secretariat: The Energy Charter Treaty and Related Documents, Annex G, and Declarations 7(a) to 7(f) related to this Annex.

${ }^{39}$ For a detailed explanation of the Treaty, see Energy Charter Secretariat, Reader's Guide to the Energy Charter Treaty, accessible at: http://www.encharter.org/ 
principles that are applicable to foreign investments in this field, ${ }^{40}$ but it is not a pure investment agreement, since it also regulates other economic activities, in particular trade in goods. ${ }^{41}$

\section{Protection of Foreign Direct Investments in the Energy Sector}

One of the aims of the Treaty is to protect investments and investors in the energy sector. ${ }^{42}$ They are being protected against non-commercial (political) risks which can materialize in various forms of governmental interference with the foreign investment or inaction of the State to the detriment of the foreign investor. ${ }^{43}$

Part III of the ECT, entitled Investment Promotion and Protection, provides rules on treatment of investments and their protection from expropriation and other non-commercial risks. Articles 10-17 constituting Part III are considered to be the cornerstones of the Treaty. ${ }^{44}$ They regulate the situation when an investor of one Contracting Party engages in an investment in the area (territory) of the other Contracting Party.

Two phases are distinguished: pre-investment and post-investment phase. ${ }^{45}$ The first one encompasses the period before the investment is made. The obligations of the host country in the pre-investment phase are defined in Art. 10(2)-10(6), and by first sentence of Art. 10(1). Each Contracting Party is bound to "encourage and create stable, equitable, favourable and transparent conditions for Investors of other Contracting Parties to make Investments in its Area." "[A]s regards the Making of Investments in its Area" each Contracting Party "shall endeavour" to accord to Investors of other Contracting Parties national treatment or the most favored nation treatment, whichever of these is more favorable. This is a "soft provision" ${ }^{46}$ that was supposed to be eventually transformed into a binding obligation by signing of a supplementary treaty (pursuant to Art. 10(6)), which never took place. ${ }^{47}$

${ }^{40}$ For a list of international bilateral and multilateral treaties regulating peaceful use of nuclear energy see the document accessible at: http://www.oecd.org/dataoecd/12/1/39055297.pdf

${ }^{41}$ R. Happ, op.cit. p. 335.

42 Ibidem, p. 331.

${ }^{43}$ Ibidem, p. 340.

${ }^{44}$ K. Hober, Investment Arbitration and the Energy Charter Treaty, 1(1)Journal of International Dispute Settlement, 153-190 (2010), accessible at: http://jids.oxfordjournals.org/content/1/1/153.full.

45 Energy Charter Secretariat: The Energy Charter Treaty and Related Documents, Introduction, p. 14. See, also: T.W. Wälde, International Energy Investment, p. 213; K. Hobér, op.cit.

${ }^{46} \mathrm{~K}$. Hobér, op.cit.

47 On the impediments to concluding the supplementary treaty, see S. Elshihabi, The Difficulty Behind Securing Sector-Specific Investment Establishment Rights: The Case of the Energy Charter Treaty, 35 International Lawyer 137 (2001), pp. 148-155. 
Once the investment is made, the Contracting Party acquires a Treatybased obligation to provide national or the most-favored nation treatment (whichever is more favorable) "to Investments in its Area of Investors of other Contracting Parties, and their related activities including management, maintenance, use, enjoyment or disposal" (Article 10(7)). Post-investment obligations are binding and enforceable through the dispute resolution mechanism laid down in Part V of the Treaty.

The distinction between these two phases may become relevant if extensive preparatory expenditures are made by the investor in expectation of future investment which eventually does not materialize. These expenditures may not be recoverable within the dispute resolution mechanism of the ECT. Drawing the dividing line between pre-investment and post-investment phase may not always be so easy, which may turn out to be a source of additional controversies.

\section{The protected investor and investment}

The protection guaranteed by provisions of Part III is accorded to investments made by investors, as defined by the ECT. ${ }^{48}$ The definition of (foreign) investment is found in Art. 1(6):

"Investment" means every kind of asset, owned or controlled directly or indirectly by an Investor and includes:

(a) tangible and intangible, and movable and immovable, property, and any property rights such as leases, mortgages, liens, and pledges;

(b) a company or business enterprise, or shares, stock, or other forms of equity participation in a company or business enterprise, and bonds and other debt of a company or business enterprise;

(c) claims to money and claims to performance pursuant to contract having an economic value and associated with an Investment;

(d) Intellectual Property;

(e) Returns;

(f) any right conferred by law or contract or by virtue of any licences and permits granted pursuant to law to undertake any Economic Activity in the Energy Sector.“

This definition of Investment starts with a wide formula ("every kind of asset") illustrated by a list of six types of rights. It is followed by a clarification contained in the second paragraph, not reproduced here (covering changes in form, and a temporal qualification of the investment). Finally, in the third paragraph it ends with a restriction as to the types of economic activity included in the definition of investment:

\footnotetext{
${ }^{48}$ For a detailed analysis of these notions under the ETC, see, A. Turinov, "Investment" and "Investor" in Energy Charter Treaty Arbitration: Uncertain Jurisdiction op.cit.
} 
"Investment" refers to any investment associated with an Economic Activity in the Energy Sector and to investments or classes of investments designated by a Contracting Party in its Area as "Charter efficiency projects" and so notified to the Secretariat."

The wide definition reflects a standard wording of investment treaties and the restriction reflects the purpose of the Energy Charter Treaty to promote long term cooperation in the energy sector. ${ }^{49}$

In AMTO v. Ukraine ${ }^{50}$, the Respondent's jurisdictional objection was that AMTO's shares in EYUM-10 did not constitute a qualified Investment under the ECT, because they did not satisfy the requirements of the last paragraph of Article 1(6) in that these shares were not "associated with an Economic Activity in the Energy Sector". AMTO was a corporation organized pursuant to the laws of Latvia that owned $67 \%$ of shares in EYUM-10, a closed joint stock company registered in Ukraine. EYUM-10 was the legal successor of a state entity that had participated in the construction of the Zaporozhskaya AES nuclear power plant in Ukraine ("ZAES"), and later became a supplier of services to ZAES.

The Arbitral Tribunal held that shares that the Claimant owned in EYUM10 constituted a kind of asset owned by the Claimant within the definition of the first part of Art. 1(6) ECT. ${ }^{51}$ To dispose of the Respondent's argument that the shares were not "associated with an Economic Activity in the Energy Sector", the Tribunal had to interpret the meaning of this phrase from the final part of Art. 1(6). In its analysis the Tribunal stated that the restriction found in the final part of Art. 1(6) was open-ended. It did not require an Investment to be an Economic Activity in the Energy Sector, but only to be "associated with" such an activity. To establish whether Claimant's investment fulfilled this condition, the definition found in Art. 1(5) of the ECT had to be taken into account:

"5. 'Economic Activity in the Energy Sector' means an economic activity concerning the exploration, extraction, refining, production, storage, land transport, transmission, distribution, trade, marketing, or sale of Energy Materials and Products except those included in Annex N1, or concerning the distribution of heat to multiple premises."

In search of a further clarification, the Tribunal noted that the Final Act by which the ETC was adopted also contained certain understandings of Contracting Parties in respect to the ECT, including Understanding 2 in relation to Articles $1(5)^{52}$ :

49 AMTO v. Ukraine, Institute of the Stockholm Chamber of Commerce Arbitration № $080 / 2005, \S 36$.

50 AMTO v. Ukraine, Institute of the Stockholm Chamber of Commerce Arbitration № 080/2005, accessible at http://www.encharter.org/

${ }^{51}$ Ibidem, $\S 39$.

52 Ibidem, § 38 . 
"(b) The following activities are illustrative of Economic Activity in the Energy Sector:

(i) prospecting and exploration for, and extraction of, e.g. oil, gas, coal and uranium;

(ii) construction and operation of power generation facilities, including those powered by wind and other renewable energy sources;

(iii) land transportation, distribution, storage and supply of Energy Materials and Products, e.g., by way of transmission and distribution grids and pipelines or dedicated rail lines, and construction of facilities for such, including the laying of oil, gas, and coal-slurry pipelines;

(iv) removal and disposal of wastes from energy related facilities such as power stations, including radioactive wastes from nuclear power stations;

(v) decommissioning of energy related facilities, including oil rigs, oil refineries and power generating plants;

(vi) marketing and sale of, and trade in Energy Materials and Products, e.g., retail sales of gasoline; and

(vii) research, consulting, planning, management and design activities related to the activities mentioned above, including those aimed at Improving Energy Efficiency."

The Tribunal found that EYUM-10's contracts related to electrical installation, repairs and technical reconstruction or upgrading -- in short, the provision of technical services -- at the ZAES nuclear power plant. ${ }^{53}$ In Respondent's view, the provision of technical services did not fall within the definition of "Economic Activity in the Energy Sector" found in Article 1(5). Although Understanding 2 of the Final Act included amongst activities illustrative of Economic Activity in the Energy Sector the "construction and operation of power generation facilities", the Repondent emphasized that the Understandings were not part of the ECT and could not be used to extend or modify the definition in Article 1(5); in any event the definition was compound and Claimant's activities definitely did not involve or concern the operation of power generation facilities. The Respondent further referred to the fact that ZAES/Energoatom had dozens, if not hundreds, of contractual relationships, arguing that it was not the object and purpose of the ECT to extend investment protection to ordinary commercial transactions. A mere contractual relationship with an entity engaged in an economic activity in the energy sector was not sufficient for it to be considered "associated with" that activity. Contracts of a nuclear power station for publishing, advertising or security services were examples of contractual relationships that would not be "associated with" an Economic Activity in the En-

${ }^{53}$ Ibidem, $\S 40$. 
ergy Sector. ${ }^{54}$ EYUM-10's short term case-by-case relationships with ZAES in respect of repair and reconstruction works "did not have such integrity and stability" as to justify ECT protection. ${ }^{55}$

According to the Tribunal, "a mere contractual relationship with an energy producer is insufficient to attract ECT protection where the subject matter of the contract has no functional relationship with the energy sector." The phrase "associated with" must be interpreted in accordance with the object and purpose of the ECT, as expressed in Article 2. ${ }^{56}$ In the case in question, EYUM-10 provided technical services - installation, repair and upgrades -- directly related to the production of electrical energy. It provided those services through multiple contracts over a substantial period of time. In its letter to EYUM-10 dated 28February, 2002, ZAES described EYUM-10 as being a "strategic partner for 20 years" and stated that EYUM-10's services were "strategically important and directed on the reliable and safe exploitation of power units of our nuclear power plant." The close association of EYUM-10 with ZAES in the provision of services directly related to energy production meant that AMTO's shareholding in EYUM-10 was an "investment associated with an Economic Activity in the Energy Sector". For these reasons, the Tribunal found that the Claimant's shareholding in EYUM-10 was an Investment within the meaning of the Energy Charter Treaty. ${ }^{57}$

The interpretation espoused by the Tribunal potentially covers many businesses with the protective shield of the ECT Part III. It is enough that they have long-term contractual relationship with a producer of nuclear energy, and that their services are important for the producer's operation. Such an interpretation is based on the broad definition of investment adopted in Art. 1(6) of the ECT and on the explanation from Understanding no. 2.

The definition interpreted in this way surely encompasses large energyrelated construction projects conducted by foreign companies in the territories of Contracting Parties. In ICSID investment arbitrations organized under various BITs, the tribunals customarily refer to "Salini test" for definition of the protected investment. Although the test, formulated in the case Salini $v$. Morocco $^{58}$ spells out certain objective elements, or requirements for an investment to exist, ${ }^{59}$ the arbitral tribunal in this award actually recognized a

${ }^{54}$ Ibidem, $\S 42$.

${ }^{55}$ Ibidem, $\S 40$.

${ }^{56}$ Ibidem, $\S 42$.

${ }^{57}$ Ibidem, $\S 43$.

${ }^{58}$ Salini Costruttori S.p.a. and Italstrade S.p.a. v. Kingdom of Morocco, ICSID case no. Arb/00/4. Decision on Jurisdiction, 16 July 2001.Accessible at: www.worldbank.org/icsid/

59 These requirements include: contribution made by investor in performance of the activity, duration of the contract, investor participation in the risk of the transaction, and contribution to economic development of the host State. Ibidem $\S \S 52-57$. 
purely commercial construction project as a protected investment. This may be of special significance for construction of nuclear power plants and other nuclear power facilities, where the risks undertaken by the contractor may be considerable, and his contribution to economic development of the State unquestionable. For example, Lithuania is currently holding a tender for construction of a 5 billion euro nuclear power plant near the town of Visaginas. Two German companies are believed to be interested in competing to build the plant. ${ }^{60}$ If they would win, these construction contracts would most likely be covered by ECT protection as foreign investments.

It should not be forgotten that the definition of protected investment found in Art. 1(6) includes another term of art that is separately defined in the provisions that follow. This is the concept of protected investor. Investment is "every kind of asset, owned or controlled directly or indirectly by an Investor."

Pursuant to Article 1(7):

"Investor" means:

(a) with respect to a Contracting Party:

(i) a natural person having the citizenship or nationality of or who is permanently residing in that Contracting Party in accordance with its applicable law;

(ii) a company or other organization organized in accordance with the law applicable in that Contracting Party;

(b) with respect to a "third state", a natural person, company or other organization which fulfils, mutatis mutandis, the conditions specified in subparagraph (a) for a Contracting Party.

In principle, this means that the individual investor must be a citizen or permanent resident of the Contracting Party, and a corporate investor must be a company or other organization organized in accordance with the law applicable in that contracting state. According to Understanding no. 3, when there is doubt as to direct or indirect control of the Investment by the Investor, the Investor carries the burden of proof that such control exists.

In certain circumstances the Contracting Party may deny the advantages of Part III to a legal entity that fits into the definition of Art. 1(7)(a)(ii). Such right is reserved in Art. 17 of the ECT, by a clause that is usually referred to as the Denial of Advantages/Benefits. ${ }^{61}$ The purpose of that clause is to maintain reciprocity and to exclude from the protection of the Treaty the so-called "shell"

${ }^{60}$ Lithuania pleased at German support for nuclear plant, 2 November 2010, Earth Times, http://www.earthtimes.org/articles/news/351499,german-support-nuclear-plant.html.

${ }^{61}$ L. A. Mistelis, C. M. Baltag, Denial of Benefits and Article 17 of the Energy Charter Treaty, in T. E. Carbonneau, A. M. Sinopole, Building the Civilization of Arbitration, JCL Studies in Comparative Law, Wildy, Simmonds \& Hill Publishing, pp. 302-322. 
or "mailbox" companies, ${ }^{62}$ i.e. companies that were established in a Contracting Party with the purpose of obtaining its nationality, and possibly protection under the ECT, without any genuine link with that Party ("nominal nationality", "nationality of convenience" $)^{63}$. Under Art. 17(1) advantages may be denied to a legal entity "if citizens or nationals of a third state own or control such entity and if that entity has no substantial business activities in the Area of the Contracting Party in which it is organized." Under Art. 17(2) advantages may be denied to an Investment that belongs to an Investor from a country with which the denying Contracting Party does not maintain diplomatic or economic relationships.

In AMTO v. Ukraine, the Respondent purported to deny advantages of Part III to the Claimant under Article 17(1) of the ECT because the Claimant failed to prove that it was not ultimately beneficially owned or controlled by nationals of a third state and that it had substantial business activities in Latvia.

After reviewing the evidence, the Tribunal concluded that AMTO was controlled by a Russian national. ${ }^{64}$ Without resolving "a difficult interpretive issue of the whether Russia is a 'third state' within the meaning of Art. 17(1)," the Tribunal immediately proceeded to the second condition mentioned in Art. 17(1), i.e. whether AMTO had substantial business activity in Latvia. The Tribunal stated that "substantial" in the context of this article meant "of substance, and not merely of form", and that it did not mean "large". On the basis of Claimant's investment related activities conducted from rented premises in Latvia, involving employment of a small but permanent staff, the Tribunal was satisfied that the Claimant had substantial business activity in Latvia and that the second pong of Art. 17(1) test was not met. ${ }^{66}$ Therefore, Ukraine was not entitled to deny advantages of Part III of the ECT to AMTO as the Claimant. ${ }^{67}$

The standards of protection guaranteed by the ECT are similar or equivalent to standards contained in most Bilateral Investment Treaties (BITs).

\section{Protection against expropriation (Art. 13)}

The State sovereignty over its territory and energy resources implies the power to expropriate private property, even if that property belongs to foreigners. That power is not questioned in the $\mathrm{ECT},{ }^{68}$ but it is limited by certain pre-

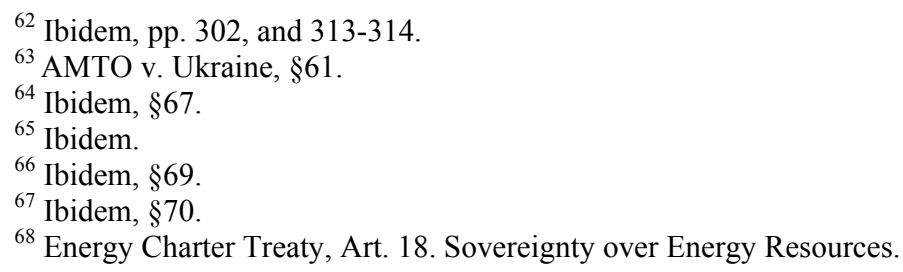


conditions that have to be fulfilled. Under Art. 13 of the ECT, the State shall not expropriate Investments of Investors unless this is

(a) done for a purpose which is in the public interest;

(b) not discriminatory;

(c) carried out under due process of law; and

(d) accompanied by the payment of prompt, adequate and effective compensation.

In other words, protection against expropriation primarily consists in the Investor's right to prompt compensation of the fair market value of the expropriated investment, calculated at the time imediately preceding the expropriation, in freely convertible currency, and with interest from the date of expropriation.

Under the title of "expropriation", Art. 13 protects investments not only against outright expropriation, but also against all measures having effect equivalent to nationalization or expropriation to which the investment may be subjected. It also expressly extends its protection in paragraph 3 to situations where the Contracting Party expropriates the assets of a domestic company in which the investor of another Contracting Party owns shares.

\section{Protection against losses (Art. 12)}

One of the non-commercial risks that is associated with investment in another State is the outbreak of war or other armed conflict, state of national emergency, civil disturbance, or other similar event in its territory. These causes are beyond power of the State, and are usually treated as force majeure in longterm contracts. The State is not held directly responsible for payment of damages arising from losses owing to such causes. Under the ECT, the Contracting Party is held responsible only to accord the Investor of any other Contracting Party with equal (non-discriminatory) treatment as regards any restitution, indemnification, compensation or other settlement that it accords to other domestic or foreign investors in such situations.

Article 12 allows for a possibility that certain losses suffered by the investor, although apparently caused by external causes, may in fact be the result of governmental measures equivalent to expropriation. In such cases, Art. 13 of the ECT applies.

If the loss is a result of requisitioning or destruction of property by State forces or authorities in situations of emergency, the Contracting Party is expressly bound under Art. 12(2) to accord to Investor of another Contracting Party prompt, adequate and effective restitution or compensation. 


\section{Standards of Treatment (Art. 10)}

\section{Fair and Equitable Treatment and Full Protection and Security}

Article 10(1) provides a set of general standards that create stable, equitable, favorable and transparent conditions for investment. Each Contracting Party has a duty to establish and maintain such conditions in its territory. They include a commitment to accord at all times to investments of investors of other Contracting Parties fair and equitable treatment and most constant protection and security.

Fair and equitable treatment and full protection and security are common standards that are generally present in the BITs. Their meaning is elusive and extremely dependent upon the particular circumstances of the case, and upon perception of different arbitral tribunals on whether certain conduct of governmental authorities was justified or not. The first standard is often invoked with regard to actions of courts or other public authorities. The second standard usually implies police protection from physical destruction of property. The question is how far the obligations of the State to guarantee constant protection and security can be stretched in situations when the action of third parties is concerned (e.g. demonstrations, riots, and other forms of public protest). Is the State obliged to do more for protection of the foreign investment than it usually does for protection of any property found in its territory? Does this clause offer more protection to foreign investors than Article 13? These issues may be of particular importance in cases of nuclear investments, because fears and suspicions of the local population inspired by rumors or lack of relevant information may easily turn into attacks against the property of the foreign investor. The State carries responsibility established in international law to inform the public on safety issues connected to the nuclear sites. ${ }^{69}$

It is not clearly stated in these provisions whether the investor is entitled to compensation in case of establishing a breach of these commitments by a Contracting Party, but arbitral tribunals routinely award compensation to claimants in such cases. Art. 14(1) that regulates transfers related to investments, speak only of "payments of compensation pursuant to Articles 12 and 13", i.e. payments of compensation for expropriation and for losses owing to force majeure. This may indicate the lack of intention on the part of Contracting Parties to award damages to investors for breach of obligations to guarantee certain standards of protection.

${ }^{69}$ See Joint Convention on the Safety of Spent Fuel Management andon the Safety of Radioactive Waste Management, IAEA INFCIRC/546, 24 December 1997, Art. 13(iii). 


\section{Prohibition of discrimination}

The Contracting Party is further prohibited by Art. 10(1) to impair management, maintenance, use, enjoyment and disposal of investments by unreasonable or discriminatory measures. In Nykomb Synergetics Technology Holding $A B$ v the Republic of Latvia ${ }^{70}$ the tribunal found that Latvia had breached its obligation under the ECT not to discriminate against the foreign investor by offering higher tariffs for electricity to other companies that were in the same situation as the foreign investor.

\section{International minimum standard}

The penultimate clauses of Art.10(1) contains obligation for the Contracting Party to apply at least such treatment of investments as required by international law (minimum standard of protection) or by another treaty. The words "or by another treaty" mean that any more favorable standard of protection that the Contracting Party has guaranteed to foreign investors of any State by another treaty, can be imported into the ECT and applied to investors of other Contracting Parties.

\section{Pacta sunt servanda}

The last sentence is qualified as an "umbrella clause" that can transform contractual obligations of the State under a commercial contract into its treaty obligations. It contains the commitment of the Contracting Party to observe any obligations it has entered into with an investor of any other Contracting Party The precise scope of this clause-in particular whether it relates to purely commercial conduct or only conduct that involves some elements of government authority - is still uncertain. ${ }^{71}$ The Contracting Parties listed in Annex IA excluded disputes arising under the last sentence of Art. 10(1) from their unconditional consent to dispute resolution in accordance with Art. 26.

\section{The National Treatment and MFN Treatment}

In addition to standards described above that already protect the investor against unjustified discrimination, the ECT spells out the relative standards of national treatment and most favored nation treatment in Art. 10(7). The clause is broadly framed so that the national and the MFN treatment must be accorded not only to investments of investors of other Contracting parties, but also to

\footnotetext{
${ }^{70}$ Nykomb Synergetics Technology Holding AB $\mathrm{v}$ the Republic of Latvia, accessible at http://www.encharter.org/

${ }^{71}$ K. Hobér, op.cit.
} 
their related activities including management, maintenance, use, enjoyment or disposal of investments.

\section{Effective means for enforcement of rights}

Under Art. 10 (12) each Contracting Party "shall ensure that its domestic law provides effective means for the assertion of claims and the enforcement of rights with respect to Investments, investment agreements, and investment authorizations." This is in effect a commitment of Contracting Parties to establish and keep in place an efficient judicial and law enforcement system.

In AMTO, the Claimant asserted a violation of Article 10(12) of the ECT by Ukraine. The Claimant submitted that Ukraine has failed to provide EYUM10 with effective means within its legal order by which to assert its legitimate claims. For a period of more than five years, EYUM-10 (and consequently, AMTO) could not enforce its rights under eleven final and binding court judgments. ${ }^{72}$ AMTO submitted that the bankruptcy legislation in Ukraine was clearly inadequate and did not live up to the standard required by international law, and accused Ukrainian authorities of interference in the bankruptcy proceedings in favor of the debtor. After reviewing the evidence, the Tribunal dismissed all of AMTO's claims related to denial of justice.

\section{Guarantee of Free Transfer of Capital and Returns (Art. 14)}

Each Contracting Party guarantees free transfer of capital and returns into and out of its territory, as specified in Art. 14(1). The transfer is to be effected without delay, in freely convertible currency (Art. 14(2)), and at the market rate of exchange existing on the date of transfer (Art. 14(3)). Certain exceptions are provided for returns in kind, and for CIS countries (Art. 14(5) and 14(6)).

There is a general reservation in Art. 14(4) allowing a Contracting Party to apply its laws and regulations, in derogation of its undertakings under Art. 14, to protect the rights of creditors, or to ensure compliance with laws on the issuing, trading and dealing in securities and the satisfaction of judgments in civil, administrative and criminal adjudicatory proceedings.

\section{State and Privileged Enterprises (Art. 22)}

An important provision for protection of foreign investors is also found beyond Part III of the ECT. It is Art. 22 that concerns State and privileged enterprises. Recognizing that the State often conducts its energy-related activities through independent entities organized for that purpose, or confers rights to

${ }^{72}$ AMTO v. Ukraine, $\S 28$. 
conduct such activities to certain privileged private enterprises, the ECT expressly constitutes certain obligations of the Contracting State with respect to conduct of those entities and enterprises. The prohibition of discrimination lies in the essence of these obligations. Most importantly, each Contracting Party must ensure that the State-owned enterprises respect the treatment of foreign investors provided in Part III when they conduct their activities, especially when they sell goods or provide services (Art. 22(1)). This means, for example, that the Contracting Party should make sure that the State-owned enterprise does not charge higher prices for fuel or energy to companies owned by investors from other Contracting Parties. ${ }^{73}$ The Contracting shall also refrain from encouraging or requiring such a State-owned enterprise to conduct its activities in the manner that is inconsistant with that Contracting Party's obligations under the ECT, either under Part III or under other Parts (Art. 22(2)).

\section{Settlement of Investment Disputes Arising under the ECT}

The ECT is the "first multilateral treaty to provide as a general rule the settlement of investor-state disputes by international arbitration"74 Dispute Settlement provisions are found in Part V which consists of three Articles. The first (Art. 26) is about disputes between the investor and the Contracting Party (host country). The second (Art. 27) is about disputes between the Contracting Parties (which may be other than investment disputes), and the third excludes application of Art. 27 to certain disputes. In addition to these rules specifically dealing with investment disputes, there are other provisions of the ECT that are related to resolution of disputes, such as Art. 6(5) providing consultation procedures for competition disputes, Art. 7(7) providing conciliation procedure for transit disputes, Art. 19(2) related to Environmental Disputes and Art. 29(7) dealing with trade disputes. $^{75}$

While the mechanism set up in Article 27 has been rarely used (only one case of a dispute between the Contracting Parties was recorded and it was settled through diplomatic channels), ${ }^{76}$ there have been 27 disputes between investors and Contracting Parties based on Article 26. ${ }^{77}$

Investors are given the right to directly initiate arbitral proceedings against a Contracting Party to the ECT, if that Party breached any of its obligations on pro-

${ }^{73}$ The Energy Charter Treaty, A Reader's Guide, p. 41.

${ }^{74}$ Plama Consortium Limited v. Republic of Bulgaria, (ICSID Case No. ARB/03/24).

${ }^{75}$ R. Happ, Dispute Settlement under the Energy Charger Treaty, Kiel, 21.02.2009, slide 6. accessible at: http://www.internat-recht.uni-kiel.de/veranstaltungen/pipeline-conference/beitraege/ Happ.pdf

${ }^{76}$ Ibidem, slide 11.

${ }^{77}$ For a list of these cases which also contains the arbitral awards that were so far rendered see: http://www.encharter.org/ 
tection of investments from Part III of the ECT. The right to arbitration is delineated by the scope of protection pursuant to Part III of the ECT, i.e. by definitions of the terms investment and investor. ${ }^{78}$ Pursuant to Art. 26(1) "Disputes between a Contracting Party and an Investor of another Contracting Party relating to an Investment of the latter in the Area of the former, which concern an alleged breach of an obligation of the former under Part III shall, if possible, be settled amicably". The proposal for an amicable settlement triggers the running of a three months "cooling off - period", ${ }^{79}$ after which the investor may initiate one of the dispute settlement procedures at his disposal enumerated in Article 26(2). These are: an action before the courts or administrative tribunals of the Contracting Party, any other previously agreed dispute settlement procedure, or, most importantly, a request for international arbitration or conciliation based on Articles 26(3)--26(8).

The right to refer the dispute to arbitration is conditioned upon attempt to reach an amicable settlement. In the dispute between AMTO and Ukraine, the Claimant asserted that there was no "cooling-off period" as a prerequisite for admissibility of a claim under the ECT. On 16 May 2005 AMTO sent the Claim Letters to Ukraine alleging a breach of the ECT to which Ukraine did not respond. Thereafter, on 31 October 2005, AMTO filed the Request for Arbitration. Ukraine stated that the Claims Letters were mere notifications of a claim, rather than requests to amicable settle an existing dispute pursuant to Art. 26(2). As there was no request for amicable settlement, the Respondent's consent under Art. 26(3) did not cover the dispute in question, and the jurisdiction of the Arbitral Tribunal was lacking. ${ }^{80}$ The Tribunal found that the Claimant did not articulate and transmit a claim pursuant to the ECT to the Respondent prior to the Claim Letters, but the Claimant and the Respondent were already parties to an existing dispute at the time of the Claim Letters. Accordingly, the Tribunal treated the Claim Letters as a request for amicable settlement pursuant to Article 26(2), and concluded that the Claimant was entitled to initiate arbitration at the expiry of the three month period. ${ }^{81}$ Additionally, the Tribunal remarked that a Contracting Party that considers the amicable settlement requirements of Article 26(2) have not been complied with by an Investor has an obligation, as a matter of procedural good faith, to raise its objections immediately. Prompt raising of objections ensures that the Investor can, if necessary, remedy the defect so that both parties are in a position to engage in the amicable settlement discussions envisaged by the ECT, and thereby help to preserve their long term cooperation in the energy sector. ${ }^{82}$

\footnotetext{
${ }^{78}$ K. Hobér, op.cit.

${ }^{79}$ R. Happ, Dispute Settlement under the Energy Charger Treaty, Slide 8.

${ }^{80}$ AMTO v. Ukraine, $\S 49$.

${ }^{81}$ Ibidem, $\S 52$.

${ }^{82}$ Ibidem, § 53 .
} 
Further argument of the Claimant with respect to the Claims Letters was that they defined the scope of the dispute that could be submitted to arbitration, so that the Claimant could not include claims in the arbitration that were not submitted to amicable settlement. ${ }^{83}$ The Arbitral Tribunal rejected this view, stating that it "misconceives the nature of the request for amicable settlement." According to the Tribunal,

"the purpose of a request for amicable settlement is to discuss the dispute, with a view to exchanging views over its causes, the interests involved, clarifying factual uncertainties and possible misunderstandings, and identifying possible solutions within the framework of the promotion of long term cooperation in the energy field based on complementarities and mutual benefits. A party can request amicable settlement of a dispute without identifying any ECT claims, and an Investor may have good reason not to formulate claims at this stage, in order to avoid taking a position or appearing to threaten the State party with arbitration before bona fide settlement discussions. The purpose of Article 26(2) -- to provide for settlement discussions -- requires the avoidance of legal forms, and the facilitation of open communication. The Investor must inform the State of the state of affairs involving disagreement, and request amicable settlement."

In Article 26(3) the Contracting Party gives an unconditional consent to submit disputes defined in Article 26(1) to arbitration. This is a unilateral "offer" of the host country to arbitrate, which is "accepted" by the investor at the moment of filing of the claim. The investor may choose between several options: ICSID arbitration, ad hoc arbitration under UNCITRAL rules, and arbitration under the auspices of the Arbitration Institute of the Stockholm Chamber of Commerce. $^{84}$

ICSID stands for International Centre for Settlement of Investment Disputes, an arbitral institution established in accordance with the Convention on the Settlement of Investment Disputes between States and Nationals of other States (1965) - usually referred to as "Washington Convention" or "ICSID Convention". ${ }^{85}$ In Art. 26(4) the ECT mentions two ways to submit an investment dispute to this arbitral institution: (i) pursuant to the Convention if both the host state and the investor's state have ratified the Washington Convention, and (ii) under the Additional Facility Rules, if one of the parties to the dispute have not ratified the Washington Convention

${ }^{83}$ Ibidem, $\S 55$.

${ }^{84}$ Seventeen of the twenty-seven disputes initiated by investors against the ECT states, both pending and concluded, have been submitted to ICSID arbitration. Of the ten remaining disputes, six have been submitted to SCC arbitration, and four to UNCITRAL arbitration.

${ }^{85} 575$ UNTS 159. The Convention is in force in 144 States. There are 155 Signatory States. See: http://icsid.worldbank.org. 
At the time of filing the claim, the investor must provide his consent in writing for the dispute to be submitted to the chosen institution or ad hoc arbitration. The arbitration agreement between the parties comes into existence in this specific way, and is considered to satisfy the requirements of the ICSID Convention and of the New York Convention on Recognition and Enforcement of Foreign Arbitral Awards.

The Respondent in AMTO v. Ukraine submitted that there was no consent on the part of the Claimant to arbitrate. ${ }^{86}$ The Respondent argued that Article 26(4)(a) of the ECT requires a separate written consent on the part of the Investor to be provided to a relevant Contracting Party to the ECT prior to commencement of arbitration which was lacking in that case. According to the Respondent, Article 26 of the ECT contains a standing offer to investors of dispute resolution by arbitration, but this "offer can operate as unconditional only to the extent that it is accepted correctly". AMTO replied that the lack of a separate written consent was of no legal consequence, since the submission of a request for arbitration was sufficient. The Tribunal ruled:

"It is well established that arbitration pursuant to an investment treaty such as the ECT requires an arbitration agreement. However, this arbitration agreement is not created by a contemporaneous exchange of promises between the parties in the manner of a commercial arbitration agreement. Rather, often offer and acceptance are separated in time and form.

...where the consent of the Investor to arbitration is in writing, unequivocal and unconditional then the ECT imposes no further formal requirements.

A request for arbitration is by its very nature a consent to arbitrate because a legal proceeding cannot be requested by a party without their own participation in the proceeding. ${ }^{17}$

\section{Two Investment Disputes in the Nuclear Sector}

Two of twenty-seven cases arising under the ECT have arisen from investments in the nuclear sector. The first that is going to be considered in detail predates the ECT. The dispute is between Hrvatska elektroprivreda d.d and the Republic of Slovenia ${ }^{88}$ It is still pending before an ICSID Arbitral Tribunal, although a "Decision on the Treaty Interpretation Issue" was rendered in 2009.

The second case between AMTO and Ukraine has already been mentioned several times in the preceding text since it is a case in which many issues concerning the interpretation of the dispute resolution provisions of the ECT have been raised. The Award in AMTO was rendered by the Tribunal on 26 March

\footnotetext{
${ }^{86}$ AMTO v. Ukraine, $\S 26$.

${ }^{87}$ Ibidem, paras 45-46.

${ }^{88}$ ICSID Case No. ARB/OS/24.
} 
2008. In this case, too, the factual pattern was interesting, because the foreign investor did not invest in a nuclear sector, but had business dealings with a nuclear power plant, and this has affected its rights in a distinctive way.

\section{HEP v. Slovenia}

The Claimant, Hrvatska elektroprivreda, d.d. (HEP), is the national electric company of Croatia, organized as a joint-stock company, wholly owned by the Government of Croatia. ${ }^{89}$ The Respondent is the Republic of Slovenia which came into existence on 25 June 1991 when its parliament declared independence from the former Socialist Federal Republic of Yugoslavia. ${ }^{90}$ In the 1970s, while they were still part of the same state, Slovenia and Croatia agreed to jointly construct and operate the Krshko Nuclear Power Plant (Krshko NPP) in Slovenia. ${ }^{91}$ For that purpose, the national electricity companies of these two countries established Nuklearna Elektrana Krshko (NEK) in 1974, as a joint venture in the form of a Yugoslav "work organization", which was later reincorporated as a limited liability company under Slovenian law. NEK still holds the license to operate the Krshko NPP. ${ }^{92}$ The construction commenced in 1974 and the plant was put in commercial operation in 1983. The plant, located just outside of the town of Krshko in south-eastern Slovenia, approximately 15 kilometers west of the border between Croatia and Slovenia, represents a significant national power resource for both countries. ${ }^{93}$ The costs of design, development and construction totaled US $\$ 1.2$ billion, and were financed from funds contributed equally by the national electricity companies of both countries. Though the Krshko NPP was initially not a foreign investment, it acquired this character in 1991, when both Slovenia and Croatia became independent States.

The financing, construction, operation, management and use of the Krshko NPP was regulated by four inter-related agreements entered into by the Socialist Republics of Slovenia and Croatia, and/or representatives of their national electricity companies in 1970, 1974 and 1982 (the Governing Agreements). ${ }^{94}$ The co-investors were to be 50:50 partners in all aspects of the plant construction,

${ }^{89}$ Source: HEP v. the Republic of Slovenia, Decision on the Treaty Interpretation Issue, 12 June 2009, §1. Accessible at: http://icsid.worldbank.org and at: http://www.encharter.org.

${ }^{90}$ Ibidem, § 2.

91 Initially, the two republics agreed to jointly build two nuclear power plants, one in Slovenia and one in Croatia. However, due to a changing political climate following the nuclear accident in Chernobyl, Ukraine, only the first nuclear power plant situated in Slovenia was built. Ibidem, para 52.

${ }_{92}$ Source: Decision on the Treaty Interpretation Issue, 12 June 2009, $§ 4$.

${ }^{93}$ Ibidem, $\S \S 3$ and 6.

${ }^{94}$ Ibidem, $§ 8$. 
management, use and operations. Each co-investor, thus, had the right to receive $50 \%$ of the power output of the plant at prices to be determined in accordance with the Agreements ${ }^{95}$ and had equal management rights in NEK. After its declaration of independence in 1991, the Slovenian Government adopted a series of measures that were viewed by HEP as inconsistent with the basic provisions of the Governing Agreements. In protest against these measures, HEP withdrew its representatives from the management board of NEK and stopped paying for electricity. On July 30, 1998, the Slovenians disconnected the electricity lines from the Krshko NPP to Croatia, terminated all electricity deliveries to HEP, and issued a Governmental "Decree" which affected HEP's rights as co-owner and manager of the plant. ${ }^{96}$ In the meantime, Slovenia had become Contracting Party to the ECT on 10 September 1997, and Croatia on 9 December 1997.

Eventually, the governments of the two countries entered into negotiations aimed at restoring HEP's rights and dispensing with unsettled claims. In mid 2001, a settlement approach, proposed by the deputy prime minister of Croatia, ultimately "broke the deadlock". ${ }^{97}$ The Minister suggested that, rather than continuing to debate past differences, the parties, should "wipe the slate clean" as of an agreed date in the future. Under his proposal, all of the parties' claims up to this agreed date would be waived and, on that agreed date, deliveries of electricity to HEP from the Krshko NPP were to be restored. At a meeting held on 9 June 2001, the Prime Ministers of Croatia and Slovenia formally endorsed the proposal, and agreed about resumption of deliveries of electricity to HEP, and waiver of all financial claims, presumably by 30 June 2002 . The settlement was recorded in the Agreement between the Government of the Republic of Croatia and the Government of the Republic of Slovenia on Regulation of the Status and other Legal Relations Regarding the Investment, Use, and Dismantling of Nuclear Power Plant Krshko signed on 19 December 2001 (the 2001 Agreement). ${ }^{98}$ However, while the Draft Agreement expressly indicated 30 June 2002 as the date for resumption of deliveries of electricity to HEP, the 2001 Agreement did not. Instead, the wording that was chosen stated that this consequence would follow upon ratification of the Agreement. The negotiators envisaged that ratification would have happened by the end of 2001 and that the 2001 Agreement would have entered into force prior to 30 June 2002. ${ }^{99}$ In fact, however, Croatia did not ratify the 2001 Agreement until 3 July $2002 .{ }^{100}$ In Slovenia

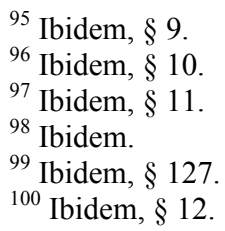


the signature and ratification of the 2001 Agreement had met with parliamentary and public opposition for a long time, and ratification happened only on 25 February 2003, following an unsuccessful attack of its constitutionality before the Constitutional Court. ${ }^{101}$ The resumption of deliveries of Krshko-generated electricity to HEP took place on 19 April 2003. ${ }^{102}$ However, the parties could not agree whether Croatia was entitled to deliveries of electricity after 30 June 2002 until that date. The Request for Arbitration was filed on 4 November 2005. In the proceeding before the ICSID Arbitral Tribunal, HEP saught compensation for the financial losses it had suffered as a result of Slovenia's failure to resume deliveries of electricity from the Krshko NPP to HEP by 30 June, 2002. HEP advanced two independent legal bases for its claim:

First, HEP alleged that Slovenia's termination of electricity deliveries to HEP on 30 July 1998, together with the issuance that same day of a Decree removing HEP's rights as a $50 \%$ owner of the Krshko NPP, violated HEP's right as an investor under Articles 10(1) and 13 of the Energy Charter Treaty (the ECT Claims). HEP contended that those violations continued until deliveries of electricity were restored to HEP on 19 April 2003. Though HEP did agree in the 2001 Agreement to waive its ECT claims accruing up to 30 June 2002, it did not waive its ECT claims that accrued during the period from 1 July 2002 to 19 April 2003. Secondly, HEP asserted a claim against Slovenia for breach of its obligation under the 2001 Agreement to restore electricity deliveries to HEP from the Krhsko NPP by June 30, 2002. ${ }^{103}$

The Arbitral Tribunal provisionally decided that the Respondent's ECT claims depended on the interpretation of the 2001 Treaty, i.e. that interpretation issue was a preliminary issue in the proceedings, and concluded that it had to be decided first. The "Decision on the Treaty Interpretation Issue" was rendered on 12 June 2009. Although it bore the title of a "Decision" this was in effect an Award, since it dismissed all claims asserted by HEP against the Republic of Slovenia under the ECT, ${ }^{104}$ witnessing a sharp division among the members of the panel over the interpretation of the 2001 Agreement concluded between the two countries. The procedure before the Tribunal continues to determine Republic of Slovenia's liability, if any, for breach of its obligations under the 2001 Agreement. Although the ECT claims were dismissed, the facts of this case are indicative of grounds that may cause disputes in the nuclear energy sector under the ECT in the future, and they deserve closer study in the context of that Treaty. The duration (from 1991-2003) and complexity of the dispute require

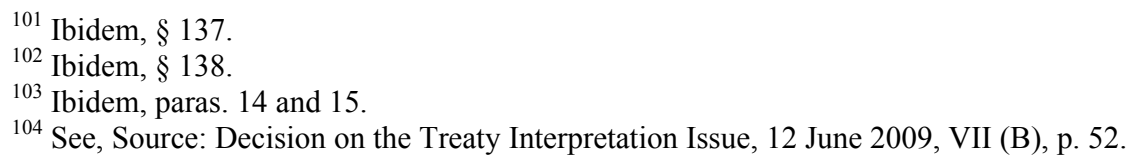


that the account be subdivided into various issues. The source of information on the pertinent facts was the Decision of the Arbitral Tribunal, which was in turn based on the Parties' memorials.

\section{Dispute over Status of the Governing Agreements}

Shortly after separation in 1991, differences began to emerge between the Government of Slovenia on the one hand, and HEP and the Government of Croatia on the other, with regard to the operation and status of the Krshko NPP and the application of the Governing Agreements. ${ }^{105}$ Negotiations started in March 1994, after the Presidents of Slovenia and Croatia agreed that legal and status questions regarding the Krshko NPP needed to be regulated with a new inter-State agreement. Slovenia's position was that the Governing Agreements did not acquire the status of a treaty and that many of their provisions were no longer appropriate in the new political and legal climate. Croatia thought that the Governing Agreements should continue to regulate Krshko NPP matters and should be elevated to the level of bilateral agreement. This issue was resolved only after the 2001 Agreement was signed on 19 December, 2001 . $^{106}$

According to the Arbitral Tribunal, "the 2001 Agreement was in general terms a settlement agreement intended to resolve the longstanding and significant differences between the two countries and to thereby enable the resumed joint operation and exploitation of NPP Krshko in accordance with the parity principle." ${ }^{107}$ The terms of the 2001 Agreement amounted to "a reincarnation of the terms of the 1970 Agreement" and upon its entry into force replaced the 1970 Agreement (Article 22(1)). ${ }^{108}$ The recitals of the 2001 Agreement stated that the two Governments took into account the Governing Agreements, and that the Agreement was based on the Energy Charter Treaty, the Convention on Nuclear Safety, and the Joint Convention on the Safety of Spent Fuel Management and on the Safety of Radioactive Waste Management. ${ }^{109}$

\section{Dispute over Ownership}

It was Slovenia's view that the Governing Agreements were to be understood and interpreted within the context of the socialist political and legal regime of former Yugoslavia at the relevant time. Pursuant to that understanding, the two national electricity companies were only the co-founders, but not coowners of Krshko NPP, as HEP argued. As co-founders they had specific rights

\footnotetext{
${ }^{105}$ Ibidem, para 75 .

${ }^{106}$ Ibidem, para 77.

${ }^{107}$ Ibidem, § 177.

${ }^{108}$ Ibidem, § 180.

${ }^{109}$ Ibidem, $§ 128$.
} 
and liabilities (e.g. to use a share of electricity from the Krshko NPP and to participate in the joint decision-making bodies), but no ownership rights. ${ }^{110}$

The Pooling Agreement that was concluded in 1974 between the electric power companies of Croatia, and electric power companies of Slovenia stated that the parties would:

- permanently pool the resources for construction and start-up of the Krshko NPP; and

- incorporate a joint venture company, NEK, through which they would jointly build, operate and use the Krshko NPP. ${ }^{111}$

Each of the Parties would cover $50 \%$ of the construction expenses and be liable for $50 \%$ of the total liabilities of NEK. Concerning the management structure of NEK, the 1974 Pooling Agreement stipulated that the Management Board would have twenty-two members, with each party appointing ten members and the parties jointly appointing two additional members. Clause 21.3 stipulated that NEK "shall take care to fill the managerial and the key work posts in such a manner that the Parties are represented in equal proportions." 112

Concerning the electricity produced by the Krshko NPP, the 1974 Pooling Agreement stated that:

- each of the parties would be entitled to receive $50 \%$ of the total available power and electricity generated by the plant;

- the parties would jointly establish the price of power from Krshko NPP, and any profit would be allocated between the Parties in a 50:50 proportion; and

- all risks associated with the operation of Krshko NPP would be shared 50:50 by the parties. ${ }^{113}$

The 1982 Self-Management Agreement was entered into between Electric Power Industry Companies of Slovenia, the Electric Power Industry Companies of Croatia, and Krshko NPP, in the process of incorporation. ${ }^{114}$ It provided for the appointment of the Board of Directors and the Management Board of NPP Krshko. The Board of Directors was to consist of twelve members, four to be appointed by the electricity companies of each of the two Republics, and four to be appointed by NEK. The Management Board was to consist of six members, three appointed by the Slovenian companies and three by the Croatian ones. The Slovenian national electricity companies would appoint the Chairman of the Management Board, the Manager of the Economic and Finance Division, and the Manager of the General, Legal and Personnel Division. The Croatian na-

\footnotetext{
${ }^{110}$ Ibidem, § 69.

${ }^{111}$ Ibidem, $\$ 58$.

${ }^{112}$ Ibidem, § 59.

${ }^{113}$ Ibidem, § 60 .

${ }^{114}$ Ibidem, § 65 .
} 
tional electricity companies would appoint the Vice-Chairman of the Management Board, the Manager of the Engineering Division, and the Manager of the Commercial Division. ${ }^{115}$

These provisions demonstrate that the parties had all rights that usually pertain to owners, such as rights of management, right of use, right to produce, etc. Nevertheless, controversy over ownership continued and was ended only after signing of the 2001 Agreement, which:

- recognized HEP and ELES-GEN ${ }^{116}$ as the legal successors in interest to the Slovenian and Croatian companies that invested in the construction of Krshko NPP;

- provided that HEP and ELES-GEN shall have equal rights and obligations, unless otherwise stated in the Agreement;

- established HEP and ELES-GEN as 50:50 shareholders in the limited liability company NEK ltd., a new legal entity to be governed by a Memorandum of Association, enclosed to the Agreement;

- stated that the governance of NEK ltd. was to be exercised in the following manner: ELES-GEN nominates the Chairman of the Management Board and HEP the Vice-Chairman. HEP nominates the Chairman of the Supervisory Board and ELES-GEN the Vice-Chairman. The Chairman of the Management Board has a casting vote, which vote is to be controlled by the Supervisory Board, ${ }^{117}$

Undoubtedly, these provisions gave HEP equity rights in NEK, and therefore recognized HEP as indirect owner of the $50 \%$ of NPP Krshko.

\section{Dispute over Delivery and Price of Electricity}

One of the most important points of disagreement was whether NEK was entitled to cut-off the electricity supply from HEP in case of non-payment and how was the price of electricity to be determined. Another point of disagreement was whether HEP's electricity bill should include decommissioning costs that were introduced by a regulatory measure of the Slovenian government in 1994.

As already mentioned, the 1974 Pooling Agreement provided that:

- each of the parties would be entitled to receive $50 \%$ of the total available power and electricity generated by the plant; and

- the parties would jointly establish the price of power from Krshko NPP, and any profit would be allocated between the Parties in a 50:50 proportion.

${ }^{115}$ Ibidem, § 67.

116 The Slovenian electric power transmission company.

${ }^{117}$ Ibidem, § 129. 
Clause 17.1.2 of the 1974 Pooling Agreement read:

"In case the Party from SR Slovenia fails to provide to the Party from SR Croatia the use of power and electricity from NE Krshko pursuant to provisions hereof because it has used the power and electricity itself, it shall compensate to the Party from SR Croatia the difference in price of power plants or from other territories due to such failure, including the electricity acquired abroad, taking into account the reasonable nature of offers for supply as regards the price." ${ }^{118}$

According to the 1982 Self-Management Agreement, Krshko NPP was to supply electricity only to the electricity companies of the two countries in equal proportions, and the price of electricity was to be mutually determined by the two companies for each business year in advance. The price of electricity was to include elements such as "costs, investment maintenance and depreciation." 119

During 1997, when the dispute was accelerating, HEP would not pay the amount as established in NEK's invoices. HEP insisted that it would pay US2.05 cents/KWh, even though, according to Slovenia, the actual operating costs in 1997 required a price of US3.0841 cents/KWh (not including decommissioning costs). Slovenia claimed that HEP continued to make only partial payments, and even stopped paying for electricity altogether as of 15 March 1998, which HEP denied. ${ }^{120}$

On 30 July 1998 NEK suspended its electricity deliveries to HEP. ${ }^{121}$ According to HEP, two transmission lines from Krshko NPP to HEP were disconnected. HEP claimed that decision to disconnect these transmission lines was made jointly by the Slovenian Minister of Economic Affairs, General Manager of ELES, the Slovenia-appointed Chairman of the Temporary Management Board of NEK, and by General Manager of NEK. ${ }^{122}$ Slovenia denied this and pointed out that the deliveries to HEP were suspended because HEP would not pay for the electricity. As a consequence, NEK did not have the necessary funds to secure safe operation and had to seek alternative buyers for the electricity. ${ }^{123}$ Slovenia also emphasized that the termination of electricity supply to HEP was intended to be only a temporary measure, ${ }^{124}$ and further asserted that there was no physical cut-off at all, i.e. that throughout the relevant period Croatia continued to receive electricity from the Krshko NPP in the same way as it had done before. The "cutoff" occurred merely on the contractual plane, because over this period HEP was deemed obliged to purchase electricity from other suppliers.

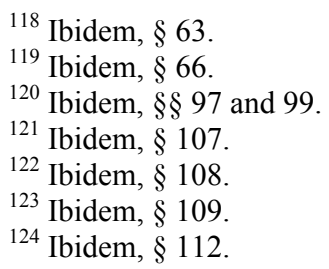


In October 1998 Slovenia proposed conditions for an agreement for the resumed delivery of electricity from the Krshko NPP to HEP. The proposal included an offer of electricity at the same price to both ELES and HEP. ${ }^{125}$ Decommissioning costs were excluded from the offered price. Croatia rejected this proposal on 10 November 1998, considering that accepting the offer would put HEP in the position of a buyer (rather than owner). Croatia also complained that the proposed production expenses were too high and not competitive. ${ }^{126}$ In January 2000 Slovenia made another offer to restore the electricity supply to HEP for a period of two years. HEP again rejected, considering the price too high. ${ }^{127}$

The 2001 Agreement:

- ordered that electricity produced at the Krshko NPP shall be delivered to the shareholders in equal proportions;

- stated that the price for electricity deliveries comprises operating costs in the amounts necessary for long-term investment, and includes, inter alia, the depreciation costs; ${ }^{128}$

- stipulated that decommissioning and radioactive waste disposal are joint liabilities of Croatia and Slovenia and shall be financed in equal proportions (i.e. they are not included in the price of electricity). The funds for decommissioning shall be collected in a special fund created by each State;

- The Memorandum of Association of NEK (enclosed to the Agreement) stated that NEK may terminate electricity deliveries to either shareholder if that shareholder fails to comply with its financial obligations);

However, as mentioned before, the 2001 Agreement failed to precisely indicate the obligaton of NEK to resume deliveries of electricity to NEK on a specific date.

\section{Dispute over decommissioning costs and costs of disposal and storage of radioactive waste}

The Governing Agreements did not deal with the issue of disposal or storage of radioactive waste. The only relevant provision was Clause 17.4.1 of the 1982 Annex to the 1974 Pooling Agreement:

"The Parties shall take all measures to provide, upon completion of construction of NE Krshko, the security measures for prevention of possible adverse consequences for the human environment. The costs of performance of measures from the previous paragraph, together with the costs arising from

\footnotetext{
125 Ibidem, § 113 .

${ }^{126}$ Ibidem, § 113 .

127 Ibidem, § 114.

${ }^{128}$ Ibidem, § 129.
} 
disposal of nuclear fuel and radioactive waste shall be borne by the Parties from each Republic in proportion 50:50."

Clause 9 of the 1970 Agreement provided a kind of stabilization clause:

"The Republics agree and understand that, in the case the economic measures and instruments are introduced in any of the two Republics, which adversely affect the construction or use of the joint nuclear power plant, as compared to the conditions in force at the beginning of its construction, such measures and instruments shall not have any effect on the rights and liabilities of the investors from the other Republic." ${ }^{129}$

In December 1994 the Slovenian Parliament adopted the "Law on the Fund for Financing the Decommissioning of the Krshko Nuclear Power Plant and the Disposal of Radioactive Waste of the Krshko Nuclear Power Plant". ${ }^{130}$ This law offered Slovenia very wide powers concerning the establishment of the decommissioning program. ${ }^{131}$ It was enacted without any consultation with HEP. Slovenia claimed that the law was a necessary measure in order for it to comply with its international obligations as a nuclear State to create a Decommissioning Fund. Under the 1994 Law, the Krshko NPP became liable for payments to the Decommissioning Fund on a monthly basis. The payments were collected by NEK by means of a surcharge factored into the selling price of the electricity produced by Krshko NPP. The intention was that an equal amount would be charged to both HEP and ELES, and that contributions collected from the buyer from each State would be credited towards that State's $50 \%$ share of the total cost of decommissioning. However, due to unilateral introduction of the measure, Croatia would not pay its share of the decommissioning costs. ${ }^{132}$

On 13 September 1997 an agreement was signed between the Croatian and Slovenian Ministers of Economy, according to which the price of electricity would be calculated "ex plant" for both buyers and decommissioning costs would not be included in the price of electricity, as each State would regulate independently its share of the costs pending the execution of a new bilateral agreement. ${ }^{133}$ Following the 1997 Agreement, however, NEK's invoices sent to HEP continued to include decommissioning charges ${ }^{134}$ and HEP continuously refused to pay.

The 2001 Agreement stipulated that decommissioning and radioactive waste disposal are joint liabilities of Croatia and Slovenia and shall be financed

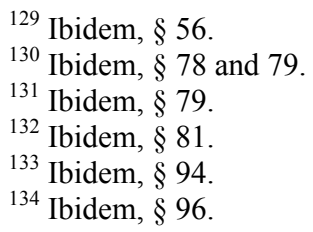


in equal proportions. The funds for decommissioning shall be collected in a special fund created by each State. ${ }^{135}$ All previous obligations of NEK to the Decommissioning Fund ceased to exist. ${ }^{136}$

\section{Dispute over Modernization}

On 10 February 1995 the NEK Management Board decided to make replacement of the steam generators. ${ }^{137}$ The Board appointed an Operational team of two Croatian and two Slovenian representatives to supervise the steam generator replacement project. ${ }^{138}$ In September of the same year, however, the Government of Slovenia issued a "Decision Supporting the Modernisation Programme" in which it announced that: "In the preparation and realization of the renovation of the NPP Krshko, the Nuclear Power Plant Krshko shall act in the capacity of the investor." ${ }^{139}$ According to HEP, General Manager of NEK, a Slovenian national, following the Decision of his Government proceeded on his own with respect to the plant modernization program. He invited HEP to presentations on the progress of the steam generator replacement program, but did not form the Operational team to manage the modernization process, as the 1995 Board decision requested. ${ }^{140}$ Due to these reasons HEP refused to pay its part of the costs for the modernization of Krshko NPP. ${ }^{141}$

The solution to this problem was found in Exhibit 3 of the 2001 Agreement entitled "Principles of the Structuring of Financial Relations". According to these principles the remaining long-term financial obligations arising out of NEK's modernization project shall be borne through the cost of electricity by the Shareholder from the Republic of Slovenia until 30 June 2002, and from that day forward by both Shareholders. ${ }^{142}$

\section{Dispute over the Appointment of NEK's Deputy General Manager}

The 1982 Self-Management Agreement provided that the incorporators from Croatia were to appoint the Deputy General Manager of NEK. In February 1996 the Deputy General Manager of NEK resigned. By letter dated 4 September 1996, addressed to General Manager, HEP nominated Mr Vrankich, a Croatian national, as Deputy General Manager. However, General Manager rejected

\footnotetext{
135 Ibidem, § 129.

${ }^{136}$ Ibidem, § 129.

${ }^{137}$ Ibidem, $\S 82$.

${ }^{138}$ Ibidem, § 83 .

${ }^{139}$ Ibidem, $\S 82$.

${ }^{140}$ Ibidem, § 83-84.

${ }^{141}$ Ibidem, $\S 93$.

${ }^{142}$ Ibidem, § 132.
} 
this appointment by a letter in which he noted that the Self Management Agreement had become inadequate in the section concerning personnel, that personnel decisions should be based on "safety, stability and operational efficiency", and that candidates for managerial positions had to be qualified in the fields of nuclear technology and safe operation of power plants, which qualifications Mr Vrankich lacked. ${ }^{143}$

In May 1997, in response to continuing differences between the Croatian and Slovenian members of the NEK Management Board, the Government of Slovenia created a "Temporary Management Board", consisting of four members nominated by each founder, to oversee NEK. ${ }^{144}$ In a letter dated 9 February 1998, the Slovenian Ministry of Economic Affairs informed the Chairman of NEK's Temporary Management Board that it agreed to the appointment of $\mathrm{Mr}$ Vrankich. The Temporary Management Board authorised General Manager to appoint Mr Vrankich as Deputy General Manager. General Manager, however, again refused, persisting in his opinion that Mr Vrankich did not possess the necessary qualifications (for example, a Senior Reactor Operator Licence). ${ }^{145}$

At a meeting of the Temporary Management Board on 24 April 1998, HEP withdrew its consent to the nomination of General Manager of NEK and declared that it would only resume its participation on the Temporary Management Board once Mr Vrankich was installed as Deputy General Manager. At the same meeting HEP declared that since Mr Vrankich had not been appointed Deputy General Manager, after 15 March 1998 HEP would not pay for the electricity it took from the Krshko NPP. ${ }^{146}$ Slovenia's defense was that General Director's point was not that HEP did not have the right to nominate NEK personnel, but "only that such right was constrained by overearching safety imperatives." Neither the Temporary Management Board nor General Manager were competent to waive mandatory conditions set out in NEK's Safety Analysis Report or NEK's operating licence. HEP's arguments were that before Mr. Vrankich's appointment NEK has had three Deputy General Managers who did not have SRO licences, and that the Government of Slovenia eventually consented to Mr Vrankich's appointment, even though he did not have the SRO licence. ${ }^{147}$

\section{Dispute over HEP's Financial Obligations towards the Krshko NPP}

NEK operated the Krshko NPP on a cost-covering basis and its sole source of revenue came from selling the electricity produced by the plant. Slovenia

\footnotetext{
${ }^{143}$ Ibidem, § 85.

${ }^{144}$ Ibidem, § 86 .

${ }^{145}$ Ibidem, § 87.

${ }^{146}$ Ibidem, § 88 .

${ }^{147}$ Ibidem, § 90 .
} 
accused Croatia of making delayed and incomplete payments for electricity it received, which lead to NEK suffering "crippling debts". ${ }^{148}$ Slovenia added that HEP did not pay its part of the decommissioning and modernization. ${ }^{149}$ The non-payment by HEP brought NEK to the "brink of operational shutdown", and to "effective insolvency" in mid-1998. ${ }^{150}$ As a result of HEP's non-payment for the deliveries of electricity, NEK did not have the necessary funds to secure its safe operation. According to HEP, Slovenia's description of NEK's finances in July 1998 was exaggerated. ${ }^{151}$ Croatia's capital, Zagreb, is located only $40 \mathrm{~km}$ downstream from the Krshko NPP, meaning that HEP was equally concerned about its safety. ${ }^{152}$ Moreover, the SNSA (Slovenia's regulatory agency) reports dealing with the Krshko NPP did not state that the financial condition of NEK had created any threat to the safe operation of the Krshko NPP. ${ }^{153}$ Slovenia responded that the reports were written in such manner in order not to cause undue public alarm, and that, contrary to HEP's submissions, most of the reports reflected concerns about NEK's financial situation. ${ }^{154}$

\section{Dispute over the Decree on Transformation}

On 31 July 1998, the Slovenian Government published a Decree on Transformation of NEK into a Public Limited Company (the "1998 Decree"), that would remain applicable until the entry into force of a bilateral agreement between Slovenia and Croatia. ${ }^{155}$ HEP claimed that a number of provisions of the 1998 Decree violated the Governing Agreements:

- Art. 1 stipulating that pending the Agreement, incorporators' rights in NEK, were to be exercised by the Government of Slovenia;

- Arts. 20 and 21, whereby in the event of a tie vote in NEK's Management Board consisting of eight members, four appointed by Slovenia and four by Croatia, the Slovenia-appointed Chairman would have a controlling vote;

- Art. 23 granted primary management responsibility to a manager, who was to be appointed by Slovenia;

- Art. 16 authorised NEK to stop delivering electricity to HEP in the event that its outstanding obligations exceeded the value of two-months' delivered electricity;

\footnotetext{
${ }^{148}$ Ibidem, § 91.

${ }^{149}$ Ibidem, § 93 .

${ }^{150}$ Ibidem, § 101.

${ }^{151}$ Ibidem, § 102.

152 Ibidem, § 104.

153 Ibidem, § 105.

154 Ibidem, § 106.

155 Ibidem, § 115.
} 
- Art. 30 stated that if an agreement on the price of electricity was not reached between NEK, ELES and HEP "within 60 days from the date of entry into force hereof, the price and terms of delivery of electricity should be determined by the incorporator", i.e. by the Slovenian Government; and

- Art. 34 required that NEK's claims against HEP with respect to "pooled depreciation resources" were to be set off against HEP's investment in the Krshko NPP, thus, according to Croatia, diluting HEP's overall percentage of ownership over the plant.

Slovenia explained that NEK had to be restructured in accordance with new Slovenian company laws. The restructuring was postponed until 1998 in hope that the negotiations between two countries would bring about a new bilateral agreement that would resolve NEK's status. From Slovenia's perspective, there was no possibility of restructuring NEK by means of an agreement with HEP, since the latter was obstructing NEK's management. No meetings of the Board of Directors were being held between 7 June 1996 and May 1997. ${ }^{157}$

On 31 December 1999 HEP commenced proceedings before the Slovenian Constitutional Court claiming that the 1998 Decree was unconstitutional and contrary to the Energy Charter Treaty. HEP's application was dismissed on 15 May 2003 on the basis that the 1998 Decree was a temporary measure. ${ }^{158}$

\section{Lessons for the future}

The main causes for disagreement between Slovenia and the Croatian Power Company have been removed by entry into force of the 2001 Agreement. The remaining dispute about compensation for non-delivered electricity in the period between 1 July and the date of entry into force of the 2001 Agreement is pending before the ICSID, and will eventually be resolved pursuant to the interpretation of that Agreement.

Although the ECT based claims of HEP founded on Arts. 10(1) and 13 of the ECT were dismissed, the conduct of Slovenia as the host country of foreign investment in a nuclear power plant in the period before the 2001 Agreement can be analyzed in the light of these two articles, in particular, in the light of their provisions on fair and equitable treatment and prohibition of expropriation without compensation.

One of the risks that accompanies foreign investment is that the ownership rights of the foreign investor will be taken, negated, or diluted by certain acts of the host state. An ownership right encompasses several rights: right to hold possession, right to use and to enjoy the produce (fruits), right to dispose. When

\footnotetext{
${ }^{156}$ Ibidem, $\$ 116$.

${ }^{157}$ Ibidem, $§ 120$

${ }^{158}$ Ibidem, § 122.
} 
the owned property is equity in a company, ownership also includes rights to manage the operation of the company and distribution of its income. Governmental interference with any of these rights may prejudice the investor's interests and, if serious enough, may amount to an indirect taking of the investment. This is why Art. 10(1) provides that "no Contracting Party shall in any way impair by unreasonable or discriminatory measures their management, maintenance, use, enjoyment or disposal" and Art. 13 mandates that investments .... "shall not be ...subjected to a measure or measures having effect equivalent to nationalization or expropriation."

In the past arbitral practice under similar provisions of BITs, the following measures have been considered to be indirect expropriation of investments: ${ }^{159}$

- measures impairing investor's right of management of his investment, such as displacement of the investor's management and appointment of managers by the government; ${ }^{160}$

- failure to protect the investment from seizure by non-state actors; ${ }^{161}$

- forced amendment of the Memorandum of Association; ${ }^{162}$

- the imposition of taxes or other charges that would substantially erode profits; ${ }^{163}$

- denial of permits necessary to operate the investment; ${ }^{164}$

- breach of contract or actions affecting contractual rights; $;{ }^{165}$

- adoption of a regulatory measure barring forever the operation of the investment; etc. ${ }^{166}$

Relying on the fact that HEP was formally not registered as the owner of NEK due to the company law of former Yugoslavia that did not recognize founders of the company as owners of its equity, Slovenia took several actions that are suspect for being contrary to the cited provisions of the ECT:

- introduction of a decommission surcharge on the selling price of electricity pursuant to the law on financing of the decommissioning and disposal of radioactive waste;

${ }^{159}$ P. Đundić, Eksproprijacija u međunarodnom privatnom pravu investicija (Expropriation in International Law of Investments), Novi Sad Faculty of Law, 2010 (doctoral thesis).

${ }^{160}$ Tippets V. TAMS - AFFA Consulting Engineers of Iran, Award No. 141-7-2 (June 29 1984), 6 Iran - U. S. C. T. R. 219 (1984).

${ }^{161}$ Wena Hotels Limited v. Arab Republic of Egypt (ICSID Case No. ARB/98/4).

${ }^{162}$ CME Czech Republic B. V. (The Netherlands) v. The Czech Republic (UNCITRAL), Final Award, March 14, 2003.

${ }^{163}$ Revere Copper \& Brass, Inc. v. OPIC, AAA, Award, August 24, 1978, 56 ILR 258.

${ }^{164}$ Metalclad Corporation v. The United Mexican States (ICSID Case No. ARB(AF)/97/1), Award, August 30. 2000; Tecnicas Medioambientales Tecmed S. A. v. The United Mexican States (ICSID Case No. ARB(AF)/00/2), Award, May 29, 2003.

${ }^{165}$ Siemens A. G. v. The Argentine Republic (ICSID Case No. ARB/02/8), Award, February 6, 2007.

${ }^{166}$ Metalclad Corporation v. The United Mexican States. 
- ordering the suspension of the deliveries of electricity (if the allegations of Croatia that the decision to disconnect was made by governmental authorities of Slovenia were proven);

- interfering in management of the investment by appointment of a Temporary Management Board and intervening in the appointment of Deputy General Manager;

- interfering in maintenance of the investment by decision regulating the modernization program;

- interfering in the enjoyment of investor's rights by enacting the decree on transformation of NPP into a Public Company which granted Slovenia the right to act as incorporator, including the right to determine the price and terms of delivery of the electricity and to play a decisive role in management decisions;

- compulsory setting off NEK's claims towards HEP with HEP's investment in Krshko NPP.

Even if these measures, taken together, did not amount to indirect expropriation, they could have been considered as contrary to obligations of Slovenia to accord fair and equitable treatment to Croatian investor, and to refrain from impairing the management, maintenance, use, enjoyment and disposal of its investment. The main argument in favor of Slovenia's actions is that these measures were of temporary character and were necessary for the uninterrupted operation of the nuclear power plant.

Some of these actions should raise particular concern of foreign investors. One of these is imposition of a decommissioning surcharge. ${ }^{167}$ Decommissioning is a process of shutting down the nuclear facility, of taking it permanently out of operation. ${ }^{168}$ Article 26 of the Joint Convention on the Safety of Spent Fuel Management and on the Safety of Radioactive Waste Management, requires that each Contracting Party shall take the appropriate steps to ensure the safety of decommissioning of a nuclear facility. Such steps shall inter alia ensure that qualified staff and adequate financial resources are available. The ultimate responsibility for accumulating funds for decommissioning rests with the State. ${ }^{169}$ The possibility that the host state will introduce or increase a decommissioning charge after the investment is made is a factor to be taken into account by every investor. For example, in the UK decommissioning costs are currently shared between the government and the regulatory authority (NDA). Seeing that the costs of decommissioning are mounting to $1 \mathrm{bn}$ pounds per annum, one UK Government official stated:

${ }^{167}$ On issues of funding of decommissioning see, OECD/NEA; Decommissioning Funding: Ethics, Implementation, Uncertainties, A Status Report, 2006.

${ }^{168}$ C. Stoiber, A. Baer, N. Pelzer, W. Tonhauser, op.cit. p. 70.

169 Joint Convention on the Safety of Spent Fuel Management and on the Safety of Radioactive Waste Management, Preamble, § vi. 
"The government is steadfast in its commitment to ensuring that future decommissioning costs do not hit the public purse. Developers investing in new build nuclear projects will be obliged to set aside money for decommissioning and clean-up operations." ${ }^{170}$

If the host government fails to oblige the investor to count in the decommissioning costs of investment from the very beginning, but decides to "change the course" at a later stage, by introducing the decommissioning charge after the investment has already been made, there may be disputes as to existence of indirect (regulatory) expropriation or unfair and inequitable treatment. The same may arise if the decommissioning charge is subsequently increased, because decommissioning costs were not properly estimated at the planning stage. It should be added, nevertheless, that according to current arbitral practice, the investor does not stand a good chance to succeed with such a claim unless he proves that the regulatory measure is discriminatory or that it totally deprived him of any benefit arising from the investment. The doctrine of police powers assures that the State cannot be responsible for damages incurred by the investor due to regulatory measures of general application. As expressed by the Tribunal in Marvin Feldman v. Mexico:

"[G]overnments must be free to act in the broader public interest through protection of the environment, new or modified tax regimes, the granting or withdrawal of government subsidies, reductions or increases in tariff levels, imposition of zoning restrictions and the like. Reasonable governmental regulation of this type cannot be achieved if any business that is adversely affected may seek compensation, and it is safe to say that customary international law recognizes this."

Unless the host government promised to the foreign investor at the time of making the investment that it will remain free of decommissioning costs, it may act in public interest and introduce the new charge at a later stage, as confirmed by the Award in Metanex:

"[A]s a matter of general international law, a non-discriminatory regulation for a public purpose, which is enacted in accordance with due process and, which affects, inter alios, a foreign investor or investment is not deemed expropriatory and compensable unless specific commitments had been given by the regulating government to the then putative foreign investor contemplating investment that the government would refrain from such regulation." 171

${ }^{170}$ Jack Craze, If we build will they come? op.cit.

${ }^{171}$ Metanex Corporation v. United States of America (UNCITRAL), Final Award of the Tribunal on Jurisdiction and Merits, August 3, 2005, Part IV Chapter D, para. 7. Accessible at: http://naftaclaims.com/Disputes/USA/Methanex/Methanex_Final_Award.pdf 
The disagreements between Slovenia and HEP over the price of electricity to be charged by the NPP Krshko bring to attention another possible stumbling block, if the roles of the investor and the State were to be reversed. The nuclear power plant constructed and operated by a foreign investor will potentially be selling electricity to customers who are citizens of the host State or to the host State itself. If the prices charged are too high, this may arouse public discontent and put pressure upon the host State to try to influence the decisions of the operator concerning the price. If the State oversteps the limits of legitimate regulation, the investor may claim expropriation or unfair and inequitable treatment. Such issues have been raised in two disputes involving foreign investments in the water supply facilities of Argentina. ${ }^{172}$ Also, the State may initially promise to the investor a certain subsidy, possibly in terms of floor prices, to attract him to invest, but later revoke this promise, as it happened in the ECT case $N y k o m b$ Synergetics Technology Holding AB v. the Republic of Latvia. ${ }^{173}$

The discontent of the Slovenian public with the fact that the rights of the Croatian investor have been recognized by the 2001 Agreement, that was one of the causes for delay in ratification of this Agreement, brings to mind other cases when the general public or local communities were dissatisfied with certain investments and caused the host governments to react to the detriment of the foreign investor. Such situations are likely to arise in connection with foreign investments in or associated with nuclear power plants and nuclear waste deposits. Under strong public pressure, the State may abuse its licensing power in order to drive the foreign investor out of the business it has originally approved. Such was the case in Tecmed v. Mexico ${ }^{174}$ in which the Arbitral Tribunal characterized the measures undertaken by Mexico as expropriation. In 1996 Tecmed bought real property, buildings and facilities and other assets relating to "Cytrar", a controlled landfill of hazardous industrial waste in the Mexican state of Sonora. Mexican regulatory agency initially issued the license to Tecmed's subsidiary to operate the landfill, but in 1998 rejected the application for renewal of the license, and adopted a resolution on the same date, whereby it requested Tecmed's subsidiary to submit a program for the closure of the landfill. The grounds for rejecting the application were certain infringements of ecological regulations committed by the investor. The Arbitral Tribunal noted that the resolution did not suggest that the infringements were so grave to com-

${ }^{172}$ Azurix Corp. v. The Argentine Republic (ICSID Case No. ARB/01/12), Award, July 14, 2006, and Compania de Augas del Aconquija S. A. and Vivendi Universal S. A. v. The Argentine Republic (Vivendi II) (ICSID Case No. ARB/97/3), Award, August 20, 2007.

${ }^{173}$ K. Hobér, Investment Arbitration in Eastern Europe: In Search of a Definition of Expropriation (Juris Net, LLC, Huntington 2007), Appendix 11

${ }^{174}$ Tecnicas Medioambientales Tecmed S. A. v. The United Mexican States (ICSID Case No. ARB(AF)/00/2), Award, May 29, 2003. 
promise public health, impair ecological balance or protection of the environment, or that they could be the reason for a genuine social crisis. Additionally, in all three cases the competent state authorities applied fines in the proportion they deemed appropriate to the importance of the infringements. ${ }^{175}$ The Tribunal recognized the existence of community or political pressure against the landfill, but concluded that community pressure and its consequences, which gave rise to the government action, were not so great as to justify depriving the foreign investor of its investment with no compensation whatsoever. ${ }^{176}$

\section{AMTO v. Ukraine}

The award in AMTO v. Ukraine resulted from arbitration pursuant to Article 26 of the Energy Charter Treaty and the Rules of the Arbitration Institute of the Stockholm Chamber of Commerce. The Claimant AMTO was a limited liability company incorporated pursuant to the laws of Latvia. ${ }^{177}$ The Request for Arbitration was filed on 31 October 2005. ${ }^{178}$

AMTO's main business activity was to act as an investment company. In late 1999 the Claimant sought an investment in the nuclear energy industry in Ukraine, and decided to buy shares in EYUM-10. This company was a legal successor of a state entity that had participated in the construction of the ZAES, the largest nuclear power plant in Ukraine. ZAES was organized as a separate division of the National Nuclear Power Generating Company "Energoatom", owned by Ukraine. At the time of the AMTO's purchase of EYUM-10's shares, EYUM-10 had established relationships with ZAES/Energoatom, and ZAES/Energoatom was EYUM-10's largest debtor. ${ }^{179}$

In 2002 and 2003 EYUM-10 commenced court proceedings and obtained eleven judgements against ZAES for various amounts of debt. ${ }^{180}$ EYUM-10 sought execution on the basis of these judgments, but execution was stayed because of bankruptcy proceedings against Energoatom. What followed were six separate bankruptcy proceedings commenced between March 2002 and December 2003 against the judgment debtor, three of which were initiated by EYUM-10. For a period of more than five years, EYUM-10 (and consequently, AMTO) were prevented from enforcing their rights under the judgments.

On May 15, 2006 EYUM-10 and Energoatom signed an Agreement relating to Energoatom's outstanding debts to EYUM-10, including the eleven

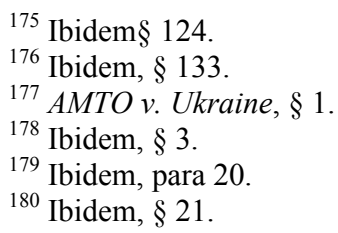


judgment debts referred to above. AMTO stated that this Agreement did not enter into force because Energoatom did not provide a required bank guarantee. Nevertheless, Energoatom made certain payments in reduction of its outstanding debt to EYUM-10. ${ }^{181}$

AMTO commenced arbitration pursuant to Article 26 ECT alleging that the Ukraine has breached various provisions of the Treaty. The Claimant referred in particular to Arts. 10(1), 10(12), and 22(1), and sought compensation and other relief. ${ }^{182}$

\section{Non-provision of funding for the State-owned debtor}

AMTO stated that Energoatom was from 12 March 2002 almost constantly being under a moratorium of payment, thus preventing EYUM-10 from enforcing its rightful claims against Energoatom. Ukaine failed to provide Energoatom with adequate funding to pay its debts. AMTO claimed that a conscious decision was taken not to provide funding to pay the debts owed to the foreign-owned EYUM-10.

The question whether Ukraine had a duty to provide funding had to be resolved under final sentence of Art. 10(1). According to Ukraine, the final sentence of Art. 10(1) (the "umbrella clause") did not apply, since the State was not involved in negotiating, executing and implementing Energoatom's obligations towards EYUM-10. It added that suppositions about the lack of funding of Energoatom were insufficient to justify the application of the umbrella clause. ${ }^{183}$ The Tribunal accepted this view finding that the non-payment by a State entity of contractual debts owed to a service provider involved no exercise of puissance publique, and could not be attributed to Ukraine. ${ }^{184}$

\section{Refusal to deal}

As a result of EYUM -10's attempts to recover its receivables by recourse to the courts of Ukraine ZAES/Energoatom -- being the monopoly buyer in the town of Energodar -- stopped ordering services from EYUM-10. AMTO claimed that there was a dramatic reduction of orders from Energoatom from 2000 onwards, and characterized this as "punishment policy" and as discriminatory conduct. ${ }^{185}$

Since there was no direct evidence of a deliberate policy to this effect the Tribunal held that the mere fall in procurement did not as of itself establish a case of discriminatory conduct.

\footnotetext{
${ }^{181}$ Ibidem, $§ 23$.

182 Ibidem, $\$ 24$.

${ }^{183}$ Ibidem, § 28.

${ }^{184}$ Ibidem, § 107.

${ }^{185}$ Ibidem, § 104.
} 


\section{Governmental measures - interference in the bankruptcy proceedings}

The Claimant submitted that the Government of Ukraine interfered in the on-going bankruptcy cases against Energoatom. As a result of interference, AMTO's investment in Ukraine, EYUM-10, was prevented from enforcing legitimate claims against Energoatom. AMTO identified three instances of such interference:

Firstly, the Cabinet of Minister of Ukraine issued an ad hoc Resolution No. 1160 of July 25, 2003. The Resolution substituted the list of "highly hazardous enterprises " composed of three generic types of power plants (nuclear power plants, water power plants and cogeneration plants) with a list featuring the actual names of the enterprises affected, including Energoatom. ${ }^{186}$ Resolution No. 1160 happened to be enacted on the same day as Energoatom filed its additional appeal against the commencement of EYUM-10's bankruptcy claim against it. AMTO considered that this Resolution was intended as a clear signal to the Commercial Court of Appeal and that it ultimately resulted in Energoatom's appeal being accepted by the court five days after the Resolution was issued.

Secondly, on 26 July 2005, shortly after the Commercial Court of Kiev finally ruled that a preliminary hearing would take place in the sixth bankruptcy case initiated by EYUM-10 against Energoatom, the Respondent introduced Law 2711-VI "On Measures to Maintain Stable Functioning of Fuel-and-Energy Enterprises" which provided Energoatom with enhanced protection against bankruptcy.

Thirdly, on 28 November 2005 by Order of the Ministry of Fuel and Energy of Ukraine Energoatom was put on the list of companies in the energy sector to which the special procedure for payment of debts according to the Law 2711-VI applied. ${ }^{187}$

Relying on the timing and content of these measures, AMTO characterized them as breaches of Articles 10(1) and 10(12) of the ECT, and in particular, as discriminatory treatment, unfair and inequitable treatment and a denial of justice. ${ }^{188}$

The Preamble of Law No. 2711-VI read:

"The objective of this Law is to support the improvement of the financial standing of the fuel-and-energy sector enterprises, prevent their bankruptcy, and enhance their investment attractiveness by regulating the procedural issues and implementing mechanisms of the debt repayment, ......

Ukraine submitted that Law 2711-IV was addressed not solely to Energoatom, but to many other enterprises as well. Pursuant to this Law, the Ministry of

\footnotetext{
${ }^{186}$ Ibidem, $\S 92$.

${ }^{187}$ Ibidem, § 29.

$188 \mathrm{I}$ Ibidem, § 90.

${ }^{189}$ Ibidem, § 22.
} 
Fuel and Energy of Ukraine issued the Order No. 568 "On Approval of the List of Enterprises", which had decided to participate in the procedure of repayment of indebtedness. Initially, this List included 440 enterprises. Accordingly, enhanced protection against bankruptcy was obtained not only by Energoatom, but by many other enterprises. ${ }^{190}$

The Tribunal concluded that AMTO did not establish any instance of State interference in the bankruptcy proceedings by these legislative enactments. ${ }^{191}$

\section{Tax inspection}

Ukraine was accused by AMTO that it tried through its tax authority and the local court to destroy EYUM-10 by imposing an injunction on EYUM-10's assets thus preventing it from using its funds and unreasonably refusing to allow EYUM-10 to make necessary payments to its staff and service providers. In addition, the Claimant has stated that the implementation of an aggressive tax inspection against EYUM-10 including the arrest of EYUM-10's assets was unreasonable and disproportionate as well as arbitrary and in breach of AMTO's legitimate expectations. Such "aggressive" conduct on behalf of Ukrainian tax authorities constituted, according to AMTO, a breach of Article 10(1), by failing to provide fair and equitable treatment and treatment that was not unreasonable or discriminatory. ${ }^{192}$ Bankruptcy proceedings were commenced against EYUM10 in November 2002 by the Regional Tax Authority, alleging non-payment of state taxes since 1998. On 8 May 2003, the court annulled the Tax Authority's decision. ${ }^{193}$

The Tribunal held that the Claimant did not demonstrate any discriminatory or unfair treatment, or any other breach of Article 10(1) arising from the actions of the Tax Authority. Noting that the Tax Authority was not the only creditor that participated in the bankruptcy proceeding against EYUM-10, the Tribunal accepted the Respondent's proposition that the Tax Authority acted in accordance with Ukrainian law, and its decisions were properly reviewed by the Ukrainian courts. ${ }^{194}$

\section{Lessons for the future}

There are various issues that appeared in this case, some of which have been already mentioned. The case can also be examined from the point of view of responsibilities of a State in a situation when the operator of a nuclear power

\footnotetext{
190 I Ibidem, § 91.

${ }^{191}$ Ibidem, § 95 .

${ }^{192}$ Ibidem, § 96.

${ }^{193}$ Ibidem, § 97.

${ }^{194}$ Ibidem, § 99.
} 
plant comes to the brink of bankruptcy. When the operator of the nuclear power plant is a State-owned company, the State bears responsibility for its safety, security, and proper functioning. Financial stability is clearly one of important aspect of the overall functioning of a nuclear power plant. What kind of governmental conduct and measures are permissible in such a situation? How far can the government go in its effort to protect the sensitive debtor of this kind from financial ruin.

The Tribunal in the AMTO case recognized the "special character" of Energoatom as an enterprise responsible for the nuclear security of the country. The Tribunal quoted Ukraine's submission:

"A bankruptcy of such an enterprise would inevitably raise a number of complex issues, which need careful and time-consuming decision-making..., the Claimant would not plausibly have legitimate expectations that Energoatom would be bankrupt within a short period of time...". ${ }^{195}$

Recognizing this and failing to find evidence of discriminatory conduct towards the foreign investment, the Tribunal did not hold Ukraine responsible for breach of its ECT obligations concerning expropriation and fair and equitable treatment. The denial of justice and umbrella clause claims were dismissed as well. Measures that Ukraine has undertaken to restore financial stability of its nuclear power plant were considered justified and legitimate. Foreign investors in companies wishing to do business with State-owned nuclear plants should bear in mind that the operators of those plants are likely to enjoy extra protection of the State in their commercial and financial dealings, and should structure their business transactions with such operators accordingly, especially by obtaining adequate security for their debts.

\section{Conclusion}

Foreign investments in nuclear energy sector are a relative novelty, and so are the disputes arising from such investments. The Energy Charter Treaty provides a set of comprehensive legal rules and standards for protection of investments against expropriation and other non-commercial risks, and an efficient mechanism for resolution of investment disputes. The only two arbitrations that have so far arisen from investments in the nuclear energy sector under the ECT, HEP v. Slovenia and AMTO v. Ukraine, provide an insight on the possible causes of misunderstandings and the ways to avoid them. They show that the involvement of State in this sector is necessary, but it must be exercised in accordance with the rules of international law.

${ }^{195}$ Ibidem, § 86 . 
Др Маја Сйанивуковић, редовни йрофесор

Правної факулиетета у Новом Саду

\section{Спорови између државе и улагача у вези са страним улагањима у сектору нуклеарне енергије: преглед два случаја настала под окриљем повеље о енергији}

\section{Сажетйк}

Идеја о могућности страних улагања у сектору нуклеарне енергије је релативно нова. Страним улагачима је дуго времена била ускраћена прилика да инвестирају у сектор који је из разлога безбедносне и економске природе сматран сувише осетљивим. Заједно са променом става према страним приватним улагањима у овој области, јавила се и могућност настанка спорова између страних улагача и државе пријема. Повеља о енергији тренутно представља једини свеобухватни правни инструмент мултилатералног карактера који предвиђа заштиту страних улагања у енергетском сектору од некомерцијалних ризика и успоставља механизам за решавање инвестиционих спорова. Овај чланак анализира случајеве ХЕП против Словеније и АМТО против Украјине, једине две арбитраже које су на основу Повеље о енергији до сада проистекле из спорова поводом страних улагања у нуклеарном сектору. Анализа показује да је учешће државе у овом сектору нужно, али да се оно мора остваривати уз поштовање права инвеститора заштићених међународним правом.

Кључне речи: страна улагања, нуклеарна енергија, Повеља о енергији, ХЕП против Словеније, АМТО против Украјине 